Dedicatória

A meu esposo Sandro, um exemplo de vida. Por estar sempre ao meu lado, me apoiando, me incentivando, me dando forças para superar todos os obstáculos. Sem a sua presença na minha vida, muitas coisas não teriam sido possíveis.

Aos meus pais, Arnaldo e Michele, minhas referências de luta e ética. 


\section{Agradecimentos}

Agradeço a Deus, por proporcionar saúde e conhecimentos para suportar e superar as muitas dificuldades enfrentadas ao longo deste caminho.

Agradeço à Professora Dra. Nélida Lúcia del Mastro, pela oportunidade e por acreditar em mim e sempre me apoiar em todos os momentos decisivos deste trabalho.

Agradeço aos pesquisadores, técnicos e colegas do Centro de Tecnologia das Radiações. Em especial á Patrícia colega para todos os momentos.

Agradeço ao Instituto de Pesquisas Energéticas e Nucleares, IPEN/CNEN-SP, pelo apoio material.

Agradeço ao Instituto de Desenvolvimento de Panificação e Confeitaria, por ceder as dependências do laboratório.

Agradeço aos meus pais, pelo constante incentivo, apoio e dedicação. Pelos valores passados por toda a minha vida.

Agradeço a meu esposo e filho, por suportar minhas ausências, pela paciência e pelo amor. 
"Estou convencido das minhas próprias limitações - e esta convicção é minha força"

Mohandas Karamchand Gandhi (1869 - 1948) 


\title{
Efeito da Radiação Gama em Propriedades da Farinha de Banana Verde
}

\section{VANESSA BERNARDO UEHARA}

\begin{abstract}
RESUMO
$\mathrm{O}$ amido de bananas tem sido pesquisado na área de nutrição a partir da introdução do conceito de Amido Resistente (AR). O amido de Musa AAA-Nanicão e Musa AABTerra já foram caracterizados quanto as suas respostas fisiológicas. A banana verde possui boa quantidade de amido resistente. $\mathrm{O}$ principal interesse em relação ao amido resistente é o seu papel fisiológico. Por não ser digerido no intestino delgado, este tipo de amido se torna disponível como substrato para fermentação pelas bactérias anaeróbicas do cólon Dessa forma, essa fração compartilha muitas das características e benefícios atribuídos à fibra alimentar no trato gastrintestinal. $\mathrm{O}$ processo de irradiação por radiação gama pode causar uma variedade de modificações nas macromoléculas, algumas de aplicação industrial, como é o caso de perda de viscosidade e alteração de textura. No presente trabalho, farinhas de banana verde (FBV) de duas origens, foram utilizadas para estudar a sensibilidade a radiação por meio de medidas de viscosidade, textura, colorimetria e $\mathrm{pH}$. As amostras de farinha de banana verde foram irradiadas com raios gama em doses de 0 a $10 \mathrm{kGy}$ e taxa de dose em torno de $2 \mathrm{kGy} / \mathrm{h}$. As soluções de FBV apresentaram-se como fluidos não-newtonianos, $\mathrm{A}$ irradiação não alterou significativamente o $\mathrm{pH}$ dos hidrogéis das farinhas de banana verde FBV1 e FBV2. A viscosidade, de maneira geral, diminuiu com a dose de radiação aplicada. Quando analisada a textura a força máxima de ruptura dos hidrogéis de FBV1 e FBV2 decresceu conforme aumento da dose de irradiação. Entretanto, em particular quando irradiada a dose de $3 \mathrm{kGy}$, a FBV2 apresentou força de ruptura aumentada.
\end{abstract}




\title{
Effect of Gamma Radiation in Properties of Green Banana Flour
}

\author{
VANESSA BERNARDO UEHARA
}

\begin{abstract}
Banana starch has been researched in the area of nutrition from the introduction of the Resistant Starch concept (RS). The starch of Musa AAA-Nanicão and Musa AABTerra had been already characterized in relation to their physiological responses. Green banana possesses important amount of resistant starch. The main interest in relation to the resistant starch is its physiological role. As it is not digested in the small intestine, this type of starch becomes available as substratum for fermentation of anaerobic bacteria of the colon. In this way, this fraction shares many of the characteristics and benefits attributed to the alimentary fiber in the gastrointestinal tract. The process of irradiation using gamma radiation can cause a variety of modifications in macro-molecules, some of them of industrial application, as it is the case of modifying viscosity and alteration of texture. In the present work, flour of green banana from two distinct origins (FBV1 and FBV2), had been used to study the radiation sensitivity by means of measurement of viscosity, texture, colorimetry and $\mathrm{pH}$. The flour samples of green banana had been irradiated with gamma rays with doses from 0 to $10 \mathrm{kGy}$, dose rate around $2 \mathrm{kGy} / \mathrm{h}$. Green banana flour solutions appeared as no-Newtonian fluids. The irradiation did not significantly modified $\mathrm{pH}$ values of green banana flour hydrogels named FBV1 and FBV2. Viscosity in general diminished with the applied radiation dose. In connection to texture analysis the maximum rupture force of the FBV hydrogels decreased with the increase of the radiation dose; FBV2 irradiated at $3 \mathrm{kGy}$ presented exceptionally increased rupture force.
\end{abstract}




\section{SUMÁRIO}

\section{Página}

1. Introdução

2. Objetivo

3. Revisão da Literatura 04

3.1.Banana. 04

3.1.1. Características 04

3.1.2. Aspectos Nutricionais $\quad 07$

3.1.3 Amido 09

3.1.4 Amido Resistente $\quad 12$

3.1.5 Alimento Prebiotico, Probiotico e Fermentação Colonica 18

3.1.6. Aspectos Tecnológicos 21

3.1.7 Farinha de Banana Verde (FBV) 24

3.2 Interação da radiação com a matéria $\quad 26$

3.3 Aplicação da irradiação em produtos alimentícios 28

3.4 Legislação 36

$\begin{array}{ll}\text { 3.5.Viscosidade } & 38\end{array}$

3.5.1 Definição 38

3.9.2 Fluidos newtonianos $\quad 41$

3.5.3 Fluidos não-newtonianos 41

3.6. Textura 42

4. Materiais e Métodos

$\begin{array}{ll}\text { 4.1 Material } & 45\end{array}$ 
4.3 Viscosimetria 45

4.4 Analise Textura 46

4.5 Colorimentria $\quad 47$

4.6 Fração sol - gel 48

5.RESULTADOS E DISCUSSÃO 49

5.1 Análise visual 49

5.2 Fração Sol Gel

5.3 Colorimetria 51

5.4 Determinação do $\mathrm{pH} 53$

5.5 Viscosimetria 64

5.6 Textura 59

6. CONCLUSÃO 65

7. Referências Bibliográficas 66 


\section{LISTA DE TABELAS}

\section{Página}

Tabela 1 Composição centesimal de bananas por $100 \mathrm{~g}$ de parte comestível.

Tabela 2 Processo digestório de carboidratos

Tabela 3 Composição centesimal e teores de amilose e AR de amido normal de milho e de banana Mussa $A A B$ Terra

Tabela 4 Aplicações da irradiação em alimentos.

Tabela 5 Composição centesimal de farinhas de banana verde com casca e sem casca, segundo Pereira, 2007.

Tabela 6 Fração sol-gel da FBV1

Tabela $7 \quad$ Valores médios de pH da FBV 1 e FBV 2 diluiídas a 3\% após aplicação de diferentes doses de radiação gama. Cada medida é a média de três repetições \pm desvio padrão. 


\section{LISTA DE FIGURAS}

Página

Figura 1 Exemplo de fluido newtoniano.

Figura 2 Exemplo de fluido não-newtoniano pseudoplástico

Figura 3 Curva típica do perfil de textura

Figura 4 Viscosímetro Brooksfield, modelo DVIII

Figura 5 Texturômetro TA-XT2 da marca Stable Micro Systems utilizado nos ensaios.

Figura 6 Extrator Sohxlet utilizado na extração de fração sol-gel 48

Figura $7 \quad$ Foto comparativa das farinhas de banana verdes estudadas $\quad 49$

Figura $8 \quad$ Analise colorimétrica da farinhas de banana verde 1 irradiada 52 em diversas doses.

Figura 9 Analise colorimétrica da farinhas de banana verde 2 iirradiada 52 em diversas doses.

Figura 10 Viscosidade em função da temperatura de amostra de FBV a 55 $5 \%$ irradiada a 3 kGy.

Figura 11 Relação entre a viscosidade aparente e tensão de 56 cicisalhamento de todas as amostras.

Figura 12 Distribuição da viscosidade média de hidrogéis de FBV a 5\% 56 com spindle $\mathrm{T}$ - $\mathrm{A}$.

Figura 13 Relação entre a viscosidade e Torque de todas as amostras. 57

Figura 14 Relação entre a viscosidade e tensão de cisalhamento de 57 todas as amostras.

Figura 15 Relação entre a tensão de cisalhamento e torque de todos os 58 compostos.

Figura 16 Viscosidade a $70^{\circ} \mathrm{C}$ em função das doses de radiação de soluções de FBV a 3\% e 5\%. 
Figura 17 Perfil de Força-Distância de hidrogel de FBV1 irradiada em diferentes doses.

Figura 18 Perfil de Força-Distância de hidrogel de FBV2 irradiada em diferentes doses.

Figura 19 Força máxima de ruptura de hidrogel de FBV1 irradiada em diferentes doses.

Figura 20 Perfil comparativo de força-distância de hidrogel de FBV 1 e 2 em doses 0 e 1 kGy pela análise de textura.

Figura 21 Perfil comparativo de força-distância de hidrogel de FBV 1 e 2 em doses 3,5 e 10 pela análise de textura. 


\section{INTRODUÇÃO}

A banana (Musa spp.), independentemente de seu grupo genômico, é, sem dúvida, uma das frutas mais consumidas no mundo. É um alimento altamente energético (cerca de $100 \mathrm{kcal}$ por $100 \mathrm{~g}$ de polpa), cujos carboidratos (cerca de 22\%) são facilmente assimiláveis. Embora pobre em proteínas e lípides, seus teores superam os da maçã, pêra, cereja ou pêssego. Contém tanta vitamina $C$ quanto a maçã, além de razoáveis quantidades de vitamina $A, B 1, B 2$, pequenas quantidades de vitaminas $\mathrm{D}$ e $\mathrm{E}$, e maior percentagem de potássio, fósforo, cálcio e ferro do que a maçã ou a laranja (EMBRAPA, 1997).

O amido de bananas tem sido pesquisado na área de nutrição a partir da introdução do conceito de Amido Resistente. O amido de Musa AAA-Nanicão e Musa AAB-Terra foram caracterizados quanto as suas respostas fisiológicas. A banana verde possui boa quantidade de amido resistente. (FREITAS e TAVARES,1998).

O principal interesse em relação ao amido resistente é o seu papel fisiológico. Por não ser digerido no intestino delgado, este tipo de amido se torna disponível como substrato para fermentação pelas bactérias anaeróbicas do cólon (JENKINS et al., 1998). Dessa forma, essa fração compartilha muitas das características e benefícios atribuídos à fibra alimentar no trato gastrintestinal (BERRY, 1986; MUIR \& O'DEA, 1992).

A preservação de alimentos pelo uso da radiação ionizante vem crescendo na indústria de alimentos para prevenir doenças e também como tratamento quarentenário. Por outro lado, o processamento por radiação pode causar uma variedade de modificações em macromoléculas todas as quais tem encontrado aplicações industriais. Essas modificações incluem: reticulação, na qual as cadéias poliméricas são ligadas com formação de redes de maior massa molecular, ou pode induzir degradação das moléculas poliméricas (VON SONNTAG, 1995). Por outro lado, alguns tratamentos físico-químicos tem mostrado capacidade de modificar 
propriedades de ingredientes ricos em amido resistente, dentre elas a viscosidade (AUGUSTIN et al., 2008) sugerindo ser esse um bom recurso para o desenvolvimento de novos produtos.

A interação da radiação ionizante com produtos naturais ricos em amido resistente não foi estudada ainda de maneira abrangente. É a proposta desta dissertação abordar o tema e contribuir com dados específicos sobre 0 comportamento de farinhas de banana verde comercializadas localmente quando submetidas à ação da radiação gama. 


\section{OBJETIVO}

Geral

Estudar a ação da radiação ionizante de ${ }^{60} \mathrm{Co}$ em propriedades da farinha de banana verde, alimento com importantes funções prebióticas .

Específico

Verificar alterações de viscosidade em diferentes concentrações e doses de irradiação;

Verificar alteração de textura em géis produzidos com farinha de banana irradiada a diferentes doses;

Analisar o comportamento de farinhas de banana verde, de diferentes produtores, quando irradiadas;

Verificar alterações de $\mathrm{pH}$ das farinhas de banana verde irradiadas. 


\section{REVISÃO DA LITERATURA}

\subsection{Banana}

\subsubsection{Características}

A banana é a fruta mais consumida no mundo e no Brasil, sendo um alimento energético, rico em carboidratos, sais minerais, como sódio, magnésio, fósforo e, especialmente, potássio. Apresenta predominância de vitamina $A$ e $C$, contendo também as vitaminas B1, B2 e B6. Contém pouca proteína e gordura. (EMBRAPA, 1997).

A banana é o fruto da bananeira (cápsula que se desenvolveu sob cultura no sentido de formar um mesocarpo carnoso e perder as sementes, sendo, pois, um tipo carpológico anômalo), também conhecido como pacoba ou pacova. A bananeira é uma grande erva da família das musáceas (Musa paradisíaca) cujas folhas, amplas, tem bainhas que se enrolam umas nas outras, formando um pseudotronco e cujo verdadeiro caule é um rizoma subterrâneo que da origem a novas bananeiras. As flores, depois os frutos, dispõem-se em cachos; os frutos, saborosos, e de grande poder alimentício, são bagas, cujas sementes já não existem (BUAARQUE DE HOLANDA FERREIRA, 1975). Brasil figura como segundo pais produtor e primeiro consumidor mundial de banana (Musa spp) que constitui um elemento importante na alimentação de populações de menor renda não só pelo valor nutritivo, mas também pelo baixo custo, sendo na sua maior parte consumida ao natural (MASTRO et al 2007).

No Brasil são encontradas diversas variedades de banana:

Banana-da-terra: chega a medir 30 centímetros. A lateral é achatada. É a variedade mais calórica. Tem $60 \%$ a mais de calorias do que a banana-pacova num pedaço do mesmo tamanho.

Banana-maçã: seu sabor residual lembra o da maçã. É a mais rica em manganês, mineral importante para o metabolismo de proteínas e carboidratos; 
Banana-nanica: o nome refere-se à árvore, que é pequena. Mas a fruta é graúda, doce e perfumada. É a mais rica em potássio;

Banana-prata: por ser pouco doce, é utilizada para fritar. Assim como a bananamaçã é boa fonte de manganês;

Banana-ouro: a menor de todas, mede até 10 centímetros. Tem um gosto bem doce e é uma das mais ricas em carboidratos;

Banana-pacova: muito comum no Norte, é usada em receitas regionais. É a mais rica em magnésio, mineral que ajuda no controle da pressão arterial. Na TAB. 1 está a composição centesimal das bananas segundo a Tabela Brasileira de Composição de Alimentos.

Tabela 1. Composição centesimal de bananas (por $100 \mathrm{~g}$ de parte comestível). (Tabela Brasileira de Composição de Alimentos - TACO, Versão 2 - Segunda Edição, Campinas - SP, 2006. www.unicamp.br/nepa/contar/taco versao 2.pdf)

\begin{tabular}{ccccccccc}
\hline Descrição & $\begin{array}{c}\mathrm{H}_{2} \mathrm{O} \\
\%\end{array}$ & $\begin{array}{c}\mathrm{E} \\
\mathrm{kcal}\end{array}$ & $\begin{array}{c}\text { Prot. } \\
\mathrm{g}\end{array}$ & $\begin{array}{c}\text { Lip. } \\
\mathrm{G}\end{array}$ & $\begin{array}{c}\text { Carboidra- } \\
\text { tos }(\mathrm{g})\end{array}$ & $\begin{array}{c}\text { Fibra } \\
\mathrm{g}\end{array}$ & $\begin{array}{c}\text { Cinzas } \\
\mathrm{G}\end{array}$ & $\begin{array}{c}\mathrm{Ca} \\
\mathrm{mg}\end{array}$ \\
\hline $\begin{array}{c}\text { Banana, da } \\
\text { terra, crua * }\end{array}$ & 63,9 & 128 & 1,4 & 0,2 & 33,7 & 1,5 & 0,8 & - \\
B. figo, crua & 70,1 & 105 & 1,1 & 0,1 & 27,8 & 2,8 & 0,8 & 6 \\
B. maçã, crua & 75,2 & 87 & 1,8 & 0,1 & 22,3 & 2,6 & 0,6 & 3 \\
$\begin{array}{c}\text { B. nanica, } \\
\text { crua }\end{array}$ & 73,8 & 92 & 1,4 & 0,1 & 23,8 & 1,9 & 0,8 & 3 \\
$\begin{array}{c}\text { B. ouro, crua } \\
\begin{array}{c}\text { B. pacova, } \\
\text { crua }\end{array}\end{array}$ & 68,2 & 112 & 1,5 & 0,2 & 29,3 & 2,0 & 0,8 & 3 \\
$\begin{array}{c}\text { B. prata, crua } \\
77,7\end{array}$ & 78 & 1,2 & 0,1 & 20,3 & 2,0 & 0,7 & 5 \\
\hline
\end{tabular}

O Brasil é o segundo maior produtor mundial de banana, com uma produção de 6,47 milhões de toneladas por ano, cerca de 9,5\% da produção 
mundial (EMBRAPA, 2005). A banana é cultivada de Norte a Sul do Brasil, tendo grande expressão econômica e elevado alcance social. É uma cultura bastante versátil, capaz de ser cultivada em diferentes ambientes, produz o ano todo e é mantenedora da fertilidade do solo, o que a torna interessante para produção por pequenos produtores, que utilizam a banana como um recurso adicional. As regiões Nordeste e Sudeste do Brasil respondem por $67 \%$ da produção nacional.

O setor de bananicultura gera hoje mais de 500 mil empregos diretos no país. Muito apreciada no Brasil e no mundo, a banana é a quarta cultura agrícola mais importante do planeta, atrás apenas do arroz, do trigo e do milho. (EMBRAPA, 2005).

Em países tropicais a banana também é conhecida como plâtano (Musa paradisíaca) que difere da banana comum por apresentar forma angular e cor verde amarelada, consumida normalmente também cozida, ainda verde. A banana ou plâtano é definida como fruta que contem amido sendo um dos principais elementos da dieta dos trópicos, quando cozida (WEBSTER'S THIRD NEW INTERNATIONAL DICTIONARY, 1976).

Embora seja uma das principais frutas brasileiras, a banana está longe de liderar as exportações para os países mais desenvolvidos, que possuem mercados muito exigentes. Segundo a FAO (2002), a participação da banana no mercado externo ainda é pouco significante, apenas 0,1 milhões de toneladas é exportada, ou seja, $1 \%$ do total. O produto nacional, de modo geral, é desqualificado para os mercados europeus e norte- americanos, pois não atende às exigências destes, principalmente em relação às qualidades organolépticas da banana (MATTHIESEN; BOTEON, 2005). Este fato é decorrente, principalmente, da defasagem nas normas de qualidade e a falta de compatibilidade com os padrões básicos vigentes nos mercados compradores da fruta in natura. Além das quantidades exportadas mínimas, o desperdício de bananas no Brasil é alto, devido às perdas pós-colheita e ao descarte de banana, chegando a $40 \%$ da 
produção, freqüentemente por não se enquadrar em padrões de aceitabilidade também do consumidor brasileiro.

Somente uma pequena parcela da produção de banana é submetida a algum processo de industrialização. Nos países e regiões menos desenvolvidos, o cultivo da banana desempenha um papel econômico e social relevante, atuando na fixação da mão-de-obra rural, gerando postos de trabalho no campo e nas cidades e contribuindo para o desenvolvimento regional (EMBRAPA, 1997 e FIORAVANÇO,2003).

\subsubsection{Aspectos Nutricionais}

Foster et al. (2003) determinaram a composição química e a distribuição de nutrientes na polpa da banana. A concentração de proteínas e minerais ( $\mathrm{Na}, \mathrm{K}, \mathrm{Ca}, \mathrm{Mg}, \mathrm{Fe}, \mathrm{Cu}, \mathrm{Zn}$, e $\mathrm{Mn}$ ) é maior na parte central, onde também é maior a concentração de fibras. $O$ ácido ascórbico ou vitamina $C$, pelo contrário, diminui a partir da parte externa até o centro. Esses mesmos autores tinham publicado anteriormente artigo no qual descrevem a possibilidade de diferenciação de bananas a partir de sua composição mineral (FOSTER et al., 2002).

A banana é um alimento rico em carboidratos (TAB 1). Contém vitaminas $A$ e $C$, é pobre em sódio, tem baixo conteúdo de lipídeos e colesterol e é rica em ácidos graxos essenciais. Contém também proteínas, que incluem três dos aminoácidos essenciais (MELLOR, 1984). Os carboidratos, quando ingeridos, estão sob forma de polissacarídeos e dissacarídeos que necessitam ser hidrolisados (quebrados) em açúcares simples para serem absorvidos. A digestão dos carboidratos, assim como de outros nutrientes, inicia-se na boca com a mastigação, que fraciona o alimento e o mistura com a saliva (SÁ, 1990). Durante esse processo, a enzima amilase salivar secretada pelas glândulas parótidas (glândula salivar situada na região orofaríngea) inicia a quebra do carboidrato em dextrinas e maltoses que são moléculas menores. Esta enzima sofre inativação 
no estômago e ai se inicia a liberação de outras enzimas locais. As fibras musculares do estômago sofrem contrações, continuando assim o processo digestivo mecânico, através dos movimentos peristálticos, que tem a função de misturar as partículas dos alimentos com secreções gástricas.

É importante ressaltar que a secreção gástrica não contém enzimas digestivas específicas para a quebra do carboidrato, ocorrendo, portanto, a movimentação do carboidrato para a parte inferior do estômago e da válvula pilórica. Após esse processo, a massa alimentar transforma-se em uma massa espessa chamada quimo, que irá ocupar o duodeno, a primeira porção do intestino delgado (SÁ, 1990). Dentro do intestino delgado os movimentos peristálticos continuam movendo o quimo ao longo do intestino delgado onde a digestão do carboidrato é finalizada através das secreções pancreática e intestinal.

As enzimas do pâncreas entram no duodeno através de um duto que contém a amilase pancreática, responsável pela continuidade do processo do desdobramento do amido e da maltose. Já as secreções intestinais contêm três enzimas distintas, as dissacaridases: sacarase, lactase e maltase, que atuam sobre os dissacarídeos dando origem aos monossacarídeos: glicose, frutose e galactose para absorção (TAB. 2).

$\mathrm{Na}$ banana verde, o principal componente é o amido, podendo corresponder até 55 a 93\% do teor de sólidos totais. Na banana madura, o amido é convertido em açúcares, em sua maioria glicose, frutose e sacarose, dos quais $99,5 \%$ são fisiologicamente disponíveis. Dependendo do cultivar, o fruto pode pesar de 100 a $200 \mathrm{~g}$, ou até mais, contendo de 60 a $65 \%$ de polpa comestível (MEDINA, 1995). 
Tabela 2. Processo digestório de carboidratos (Fonte: SÁ, 1990)

\begin{tabular}{llll}
\hline Fonte de Enzima & Enzima & Substrato & Produtos \\
\hline $\begin{array}{l}\text { Boca e Glândulas } \\
\text { Salivares }\end{array}$ & Amilase salivar & Amido & $\begin{array}{l}\text { Dextrinas } \\
\text { Maltoses }\end{array}$ \\
\hline Intestino delgado & Amilase & Amilose & Maltose, Malto- \\
Pâncreas & pancreática & Amilopectina & dextrose, dextrinas \\
\hline Mucosa intestinal & Sacaridases & Dextrinas & Glicose \\
Borda em escova & intestinais & Sacarose & Glicose, Frutose \\
& Isomaltase & Maltose & Glicose, Glicose \\
& Sacarase & Lactose & Glicose, Galactose \\
& Maltase & & \\
& Lactase & & \\
\hline
\end{tabular}

\subsection{Amido}

$\mathrm{Na}$ biosfera há, provavelmente, mais carboidratos do que todas as outras matérias orgânicas combinadas, por causa da abundância de dois polímeros da D-glicose: celulose e amido. O amido é encontrado em grandes quantidades em plantas, onde é a principal forma de armazenamento energético.

O conceito de carboidratos complexos tem sido modificado pelas descobertas relacionadas aos seus efeitos fisiológicos e nutricionais. Neste grupo de nutrientes incluem-se o amido e os polissacarídeos não-amido, os quais possuem diferenças em suas estruturas químicas e em seus efeitos fisiológicos. (LOBO, 2003)

O amido é formado por dois polímeros, a amilose e a amilopectina, que somente podem ser evidenciados após solubilização dos grânulos e separação. 
As propriedades mais importantes com influência no seu valor nutricional incluem a taxa e a extensão da digestão ao longo do trato gastrointestinal e o metabolismo dos monômeros absorvidos (LOBO 2003).

O amido é um macro-constituinte de muitos alimentos e suas propriedades e interações com outros constituintes, particularmente água e lipídeos são de interesse da indústria de alimentos e da nutrição humana (COPELAND et al. , 2009).

O amido é insolúvel em água fria, mas enche ou intumesce em água quente e ao esfriar forma uma pasta ou gel. Graças a ligações fracas entre as moléculas de amilose e de amilopectina, estas se agregam em pequenos grânulos de amido de tamanho compreendido entre 2 e 50 milésimos de milímetro. Em alguns lugares, estes agrupamentos são organizados ou cristalinos, em outros, os grânulos são amorfos e mais frágeis. Mediante o aquecimento, a energia das moléculas de água é suficiente para desordenar as regiões amorfas e estabelecer pontes de hidrogênio entre as moléculas de amido e as de água. A água se introduz aos poucos nos grânulos, que incham e cujas moléculas, progressivamente, se emulsionam com formação de géis ou gomas de alta viscosidade (THIS, 1996).

O amido pode ser hidrolisado por ácidos ou por enzimas até dextrinas e finalmente a-glicose (monossacarídeo), seguindo duas diferentes vias. A amilose pode ser hidrolisada pela enzima conhecida como $\alpha$-amilase. Esta enzima, presente no suco pancreático e na saliva, participa na digestão do amido no trato gastro-intestinal, tendo como produto da hidrólise uma mistura de glicose e maltose (dissacarídeo). A amilose pode ser hidrolisada também pela ß-amilase, que hidrolisa unidades de maltose. Os polissacarídeos de longitude de cadeia intermediária denominam-se dextrinas. A amilopectina é também atacada pelas amilases, mas é necessária a ação de uma $\alpha(1 \rightarrow 6)$-glucosidase para degradá-la até glicose e maltose. 
O abrandamento de frutas climatéricas durante o amadurecimento é geralmente atribuído à degradação no complexo da parede celular, particularmente à solubilização da pectina (LOHANI et al., 2004). Também, a hidrólise do amido e a síntese de açúcares durante o amadurecimento da banana são transformações bioquímicas importantes, havendo evidências de que ocorrem de forma homogênea no fruto.

Bassinello et al., (1999), estudaram os teores de amido, hexoses (monossacarídeos) e sacarose (dissacarídeo), bem como, a atividade das enzimas sacarose-fosfato sintetase (SPS) e sacarose sintetase (SS) em diferentes partes de banana Nanicão durante o amadurecimento. Observou-se que na banana verde existe mais amido na porção periférica (18\%) do que na central (13\%). Porém, a sua velocidade de degradação durante o amadurecimento é a mesma, o que resulta em teores diferenciados de amido residual na banana madura. Também o aparecimento e acúmulo de sacarose foi simultâneo nas duas regiões e coincidente com os valores máximos de atividade da SPS.

Além dos aspectos nutricionais, a expressão gênica diferencial no amadurecimento da banana é hoje tema de estudo em relação a dois temas extremamente importantes: o estudo de alergénicos e a produção de vacinas orais a partir de bananas transgénicas (CLENDENNEN \& MAY, 1997)(PEUMANS et al.,2002) .

Através da técnica de espectrometria de massa pela reação de transferência de prótons, Mayr et al. (2003) monitoraram on-line o padrão de comportamento de compostos voláteis característicos de banana verde (2Ehexenal e hexanal) e banana madura (acetato de isopentila e acetato de isobutila) num experimento de respiração in vivo. Eles observaram que 2E-hexenal e hexanal aumentaram durante a mastigação de banana verde o que não ocorreu 
com a banana madura. Também, os compostos orgânicos voláteis estavam em maior concentração na hora de engolir, no caso da banana madura.

A origem e as características do amido, bem como as condições de processamento (que induzem modificações estruturais) a que são submetidos os produtos amiláceos, são de grande importância e podem alterar as taxas de hidrólise in vivo e in vitro (COLONNA et al., 1992).

\subsubsection{Amido Resistente}

O termo amido resistente foi sugerido inicialmente por Englyst et al. (1982). Estes pesquisadores constataram que muitos alimentos processados continham maior teor aparente de polissacarídeos não amiláceos do que os produtos crus correspondentes. Análises detalhadas revelaram que este aumento era devido a um composto formado por n-glicoses, que podia ser disperso em hidróxido de potássio. Assim, estes pesquisadores definiram amido resistente (AR) como sendo aquele que resiste à dispersão em água fervente e hidrólise pela ação da amilase pancreática. Esta fração era constituída principalmente de amilose retrogradada, que também parecia ser altamente resistente à digestão (CHAMP \& FAISANT, 1996).

A partir de 1992, a definição para AR assumiu um caráter mais relacionado aos seus efeitos biológicos, representando "a soma do amido e produtos de sua degradação que não são absorvidos no intestino delgado de indivíduos saudáveis" (FAISANT et al., 1993; CHAMP \& FAISANT, 1996; GOÑI et al., 1996). Pode-se dizer, então, que o AR é a fração que não fornecerá glicose ao organismo, mas que será fermentada no intestino grosso para produzir gases e ácidos graxos de cadeia curta, principalmente. Devido a esta característica, considera-se que os efeitos do AR sejam, em alguns casos, comparáveis aos da fibra alimentar e, por este motivo, normalmente é considerado como um componente desta (CHAMP \& FAISANT, 1996). 
Vários métodos são utilizados para a determinação do AR; porém, nenhum é de aceitação unânime, uma vez que apresentam diferenças importantes nos protocolos e nos resultados obtidos (HOMMA et al., 2008).

A banana verde é considerada uma excepcional fonte de AR. $\mathrm{O}$ amido de bananas tem sido pesquisado na área de nutrição a partir da introdução do conceito de AR. O amido de Musa AAA-Nanicão e Musa AAB-Terra foram caracterizados quanto as suas respostas fisiológicas. A banana verde é rica (até 84\%) em AR, segundo Freitas \& Tavares (1998). Por não ser digerido no intestino delgado, o amido resistente se torna disponível como substrato para fermentação pelas bactérias anaeróbicas do cólon (JENKINS et al., 1998). Dessa forma, essa fração compartilha muitas das características e benefícios atribuídos à fibra alimentar no trato gastrintestinal (BERRY, 1986; MUIR \& O'DEA, 1992).

O índice glicêmico (IG) é um parâmetro que tem sido desenvolvido ao longo das últimas décadas. Tem sido referido como recurso para auxiliar o controle da glicemia pós-pandrial, quer em indivíduos sãos como em indivíduos com patologia diagnosticada, nomeadamente alteração do metabolismo glucídico (ex. diabéticos, insulino-resistentes). O IG representa a qualidade de uma quantidade fixa de carboidrato disponível de um determinado alimento, em relação a um alimento-controle, que normalmente é o pão branco ou a glicose. Tal índice foi proposto para auxiliar a seleção de alimentos, assim quando o alimento controle utilizado é o pão, os alimentos analisados que apresentam $I G<75$, são considerados de baixo IG. Já os alimentos com IG $>95$, são considerados de alto IG. Caso o alimento padrão seja a glicose, considera-se alto, IG $>70$, médio IG 56-69 e baixo $I G<55$. A recomendação para o uso do $I G$ baseia-se, principalmente, na substituição de alimentos de alto IG por outros de baixo IG ao longo do dia. Segundo Powell et al.(2002), o IG em relação à glicose da banana madura e verde é de 51 e 42 respectivamente. Quando o IG é medido em relação ao pão, o IG é de 73 e 60 respectivamente. 
Em indivíduos diabéticos, o consumo de carboidratos digestíveis não deve exacerbar a hiperglicemia pós-prandial e deve prevenir eventos hipoglicêmicos. As diferenças nas respostas glicêmica e insulinêmica ao amido da dieta estão diretamente relacionadas à taxa de digestão do amido (O'DEA et al., 1981). Dessa forma, alimentos lentamente digeridos ou com baixo IG têm sido associados ao melhor controle do diabetes e, em longo prazo, podem até mesmo diminuir o risco de desenvolver a doença (JENKINS et al., 1998). Em estudo realizado por Kabir et al. (1998), com ratos normais e diabéticos, a substituição do amido com alto IG por amido com baixo IG numa dieta mista aumentou a oxidação da glicose, estimulada pela insulina, e diminuiu a incorporação da glicose nos lipídios totais (WALTER, 2005).

O AR também tem sido associado a reduções nos níveis de colesterol LDL (lipoproteína de baixa densidade) e de triglicerídios na hiperlipidemia (JENKINS et al., 1988). Saquet et al. (1983) observaram que a inclusão de AR à dieta de ratos reduziu os níveis de colesterol e triglicerídios plasmáticos. Não sendo digerido no intestino delgado, o AR serve de substrato para o crescimento de microrganismos benéficos à saúde, atuando como agente prebiótico (HARALAMPU, 2000). A metabolização desse tipo de carboidrato pelos microrganismos, via fermentação, resulta na produção de ácidos graxos de cadeia curta, como acetato, propionato e butirato; gases carbônico e hidrogênio e, em alguns indivíduos, metano; e diminuição do pH do cólon (ENGLYST et al., 1987; CHAMP \& FAISANT, 1996; YUE \& WARING, 1998). A maioria destes compostos age na prevenção de doenças inflamatórias do intestino, além de auxiliar na manutenção da integridade do epitélio intestinal. Adicionalmente, o AR contribui para o aumento do volume fecal, modificação da microflora do cólon, aumento da excreção fecal de nitrogênio e, possivelmente, redução do risco de câncer de cólon (JENKINS et al., 1998; YUE \& WARING, 1998). 
$\mathrm{Na}$ TAB 3 são mostrados alguns dados da literatura (TEIXERA et al, 1998) onde são comparados os teores de AR de amido de banana e o de amido de milho.

A ingestão de AR na Europa e América Latina é reduzida (ao redor de 3-6g/dia) se comparada ao consumo de outros continentes como a Ásia (819g/dia) (MENEZES; GIUNTINI; LAJOLO, 2001; CAMBRODÓN, 2001). Entretanto, existe considerável potencial para o aumento da ingestão deste nutriente através de alimentos e produtos alimentícios com elevado teor de AR (MENEZES; LAJOLO, 2000).

Tabela 3. Composição centesimal e teores de amilose e AR de amido de milho e de banana Mussa AAB Terra (TEIXERA et al, 1998)

\begin{tabular}{ccc} 
Componente & Amido milho (\%) & Amido banana (\%) \\
\hline Proteínas & 0,33 & 0,10 \\
Lipídeos & 0,44 & 0,58 \\
Fibras & 0.05 & 0,06 \\
Cinzas & 0,03 & 0,04 \\
Amilose & 25,50 & 19,20 \\
AR & 2,5 & 49,61 \\
\hline
\end{tabular}

O AR pode ser classificado em amido fisicamente inacessível (AR1), grânulos de amido resistente (AR2) e amido retrogradado (AR3), considerando sua resistência à digestão.

- Amido resistente tipo 1 - A forma física do alimento pode impedir o acesso da amilase pancreática e diminuir a digestão do amido, fato que 0 caracteriza como resistente tipo AR1 (fisicamente inacessível). Isto pode 
ocorrer se o amido estiver contido em uma estrutura inteira ou parcialmente rompida da planta, como nos grãos; se as paredes celulares rígidas inibirem o seu intumescimento e dispersão, como nos legumes; ou por sua estrutura densamente empacotada, como no macarrão tipo espaguete (ENGLYST et al., 1992; MUIR \& O'DEA, 1992; GOÑI et al., 1996).

- Amido resistente tipo 2 - Na planta, o amido é armazenado como corpos intracelulares parcialmente cristalinos denominados grânulos. Por meio de difração de raios- $x$, podem-se distinguir três tipos de grânulos que, dependendo de sua forma e estrutura cristalina, denominam-se A, B e C. As cadeias externas relativamente curtas das moléculas de amilopectina de cereais (menos de 20 unidades de glicose) favorecem a formação de polimorfos cristalinos tipo A. Já as cadeias externas maiores das moléculas de amilopectina de tubérculos (mais de 22 unidades de glicose) favorecem a formação de polimorfos tipo $B$, encontrados também na banana, em amidos retrogradados e em amidos ricos em amilose. Embora com estrutura helicoidal essencialmente idêntica, o polimorfo tipo A apresenta empacotamento mais compacto do que o tipo $\mathrm{B}$, o qual apresenta estrutura mais aberta e centro hidratado. Por sua vez, o polimorfo tipo $C$ é considerado um intermediário entre os tipos $A$ e $B$, sendo característico de amido de legumes e sementes (THARANATHAN, 2002; TESTER et al., 2004). A forma do grânulo influencia sua digestão, caracterizando o amido resistente tipo AR2. Embora o grau de resistência dependa da fonte, geralmente grânulos dos tipos $\mathrm{B}$ e $\mathrm{C}$ tendem a ser mais resistentes à digestão enzimática (ENGLYST et al., 1992; MUIR \& O'DEA, 1992).

- Amido resistente tipo 3 - A maioria do amido ingerido pelo homem é submetido a tratamentos com calor e umidade, resultando no rompimento e gelatinização da estrutura do grânulo nativo, o que o torna digerível (BOTHAM et al., 1995). Quando o gel esfria e envelhece, o amido gelatinizado forma novamente uma estrutura parcialmente cristalina, insolúvel e resistente à digestão enzimática, porém diferente da 
conformação inicial (ENGLYST et al., 1992; MUIR \& O'DEA, 1992). Este processo é conhecido como retrogradação, caracterizando o amido resistente tipo AR3. A retrogradação da amilose, à temperatura ambiente, é um processo rápido (poucas horas), originando uma forma de amido altamente resistente a redispersão em água fervente e à hidrólise pela amilase pancreática (MUIR \& O'DEA, 1992; BOTHAM et al., 1995). Já a retrogradação da amilopectina é um processo mais lento (dias a semanas) e dependente da concentração da amostra, sendo que, em excesso de água, ela pode ser revertida por aquecimento a $70^{\circ} \mathrm{C}$ (BOTHAM et al., 1995). Vários estudos têm demonstrado relação direta entre o conteúdo de amilose e a formação de amido resistente, o que não ocorre com a amilopectina (BERRY, 1986; EGGUM et al., 1993; SAMBUCETTI \& ZULETA, 1996).

Durante o processamento e armazenamento, as mudanças ocorridas na estrutura do amido influenciam profundamente as suas propriedades funcionais e fisiológicas (COLONA,1992). A quantidade de água, o tempo e a temperatura de armazenamento são variáveis que influenciam no processo de cristalização e afetam diretamente os rendimentos do AR (ESCARPA, 1996).

A forma e a estrutura cristalina dos grânulos de amido são características de cada vegetal e podem ser visualizadas através de padrões de difração de Raios $X$, sendo divididos em três tipos: A, B e C. O tipo A é geralmente encontrado em amidos de cereais; o B é observado em alguns tubérculos, na banana verde e em amidos de milho com alto teor em amilose; e o $C$ é encontrado freqüentemente em amidos de leguminosas e sementes, sendo considerado por alguns autores, uma combinação dos tipos A e B (ENGLYST, 1992; GALLANT, 1992). Adicionalmente, quando moléculas de amilose associamse com lipídeos no grânulo de amido, é visualizado um padrão de Raios $\mathrm{X}$ tipo $\mathrm{V}$, que é parcialmente resistente à digestão enzimática (ENGLYST, 1992; GALLANT, 1992; SHI, 2001). 
Outros trabalhos mostraram que quanto maior o conteúdo de amilose, maior o rendimento do AR (POMERANZ, 1992; SIEVERT, 1991). Este efeito foi comprovado em diferentes tipos de amido, tais como os de trigo, batata e milho com alto teor em amilose, fazendo pensar que a amilose era o único componente do amido a interferir na retrogradação. Entretanto, conforme estudos posteriores revelaram, sob determinadas condições de tempo e temperatura de armazenamento, a retrogradação da amilopectina não pode excluir-se da fração total do amido retrogradado (LOBO, 2003).

\subsubsection{Alimento Probiótico, Prebiótico e Fermentação Colônica}

Os probióticos eram classicamente definidos como suplementos alimentares à base de microrganismos vivos, que afetam beneficamente 0 animal hospedeiro, promovendo o balanço de sua microbiota intestinal (FULLER, 1989). Diversas outras definições de probióticos foram publicadas (SANDERS, 2003). Entretanto, a definição atualmente aceita internacionalmente é que eles são microrganismos vivos que se administrados em quantidades adequadas, que conferem benefícios à saúde do hospedeiro (FOOD AND AGRICULTURE ORGANIZATION OF UNITED NATIONS; WORLD HEALTH ORGANIZATION, 2001).

A influência benéfica dos probióticos sobre a microbiota intestinal humana inclui fatores como efeitos antagônicos, competição e efeitos imunológicos, resultando em um aumento da resistência contra patógenos. Assim, a utilização de culturas bacterianas probióticas estimula a multiplicação de bactérias benéficas, em detrimento à proliferação de bactérias potencialmente prejudiciais, reforçando os mecanismos naturais de defesa do hospedeiro (PUUPPONEN-PIMIÄ ET AL., 2002). 
Prebióticos são componentes alimentares não digeríveis que afetam beneficamente $\mathrm{o}$ hospedeiro, por estimularem seletivamente a proliferação ou atividade de populações de bactérias desejáveis no cólon. Adicionalmente, o prebiótico pode inibir a multiplicação de patógenos, garantindo benefícios adicionais à saúde do hospedeiro. Esses componentes atuam mais freqüentemente no intestino grosso, embora eles possam ter também algum impacto sobre os microrganismos do intestino delgado (GIBSON, ROBERFROID, 1995; ROBERFROID, 2001; GILLILAND, 2001; MATTILA-SANDHOLM ET AL., 2002).

A banana está incluída no grupo de alimentos prebióticos, isto é, possuem fibras dietéticas solúveis e insolúveis e fruto-oligossacarídeos, cujas ações no nosso organismo seriam, entre outras, a de melhorar a função intestinal, retardar o esvaziamento gástrico e diminuir os índices de colesterol sangüíneo. Estudo realizado por COSTA et al. (1997) mostrara a eficácia da administração de banana (Musa paradisíaca $L$ ) verde no tratamento de úlceras gastroduodenais em tratamento prolongado por 5 semanas, em ratos. A banana verde mostrou palatabilidade semelhante à aveia e alto conteúdo energético mas com menor conteúdo em proteínas para alimentação de pequenos ruminantes como a cabra (PIELTAIN et al., 1998).

O amido resistente tipo 2, presente na banana verde, apresenta uma reduzida susceptibilidade à amilase tanto in vitro quanto in vivo em ratos e humanos (ASP et al., 1994; FAISANT et al., 1995). Faisant et al., (1995) verificaram, por técnica de intubação em indivíduos saudáveis, que o amido da banana verde é pouco digerido no intestino delgado. Semelhantes resultados foram observados por Englyst et al., (1996) empregando técnicas in vitro e in vivo com indivíduos ileostomizados.

A fermentação colônica consiste basicamente na degradação anaeróbia por bactérias microbianas de componentes da dieta e outros 
componentes endógenos que não são digeridos por enzimas intestinais nem absorvidos no trato gastrintestinal superior. Entre os principais fatores que determinam o processo fermentativo podem ser citadas a quantidade e estrutura dos substratos disponíveis, a quantidade e as espécies de bactérias colônicas e o tempo de contato entre as bactérias e o substrato (CAMBRODÓN; MARTINCARRÓN, 2001).

Em relação ao substrato, este é constituído da chamada "fração indigerível" (FI) da dieta, bem como uma porção considerável de mucina, células epiteliais, enzimas e outros produtos de origem endógena (CUMMINGS; MACFARLANE, 1991). A fração indigerível é composta, em sua maior parte, de amido resistente, fibra alimentar, proteína resistente, oligossacarídeos, lipídios, polifenóis e outros componentes associados (SAURA-CALIXTO et al., 2000; CAMBRODÓN; MARTIN-CARRÓN, 2001).

Como mencionado anteriormente, as bactérias colônicas humanas fermentam o AR e os polissacarídeos não-amido produzindo principalmente ácidos graxos de cadeia curta (AGCC) (acetato, propionato e butirato). A fermentação de alguns tipos específicos de AR favorece ainda mais alguns de seus efeitos no cólon (ANNISON; TOPPING, 1994; BERGGREN et al., 1995). Alguns efeitos dos AGCC talvez sejam decorrentes mais da diminuição do $\mathrm{pH}$ intracolonretal do que de alguma ação de um AGCC específico. $\mathrm{Em} \mathrm{pH}=6$, os ácidos biliares encontram-se protonados e insolúveis não sendo assim absorvidos pelos colonócitos (RAFTER et al., 1986). Em pH mais baixo ainda, acontece inibição da conversão de ácidos biliares primários a secundários por bactérias (MACDONALD et al., 1979; NAGENGAST et al., 1988), diminuindo assim seu potencial carcinogênico.

Alguns efeitos atribuídos aos prebióticos são a modulação de funções fisiológicas chaves, como a absorção de cálcio e, possivelmente, o metabolismo lipídico, a modulação da composição da microbiota intestinal, a qual exerce um 
papel primordial na fisiologia gastrintestinal, e a redução do risco de câncer de cólon (ROBERFROID, 2002). Diversos trabalhos experimentais mostraram a aplicação da inulina e da oligofrutose como fatores bifidogênicos, ou seja, que estimulam a predominância de bifidobactérias no cólon. Conseqüentemente, há um estímulo do sistema imunológico do hospedeiro, uma redução nos níveis de bactérias patogênicas no intestino, um alívio da constipação, uma diminuição do risco de osteoporose resultante da absorção diminuída de minerais, particularmente o cálcio. Adicionalmente, haveria uma redução do risco de arteriosclerose, através da diminuição na síntese de triglicérides e ácidos graxos no fígado e diminuição do nível desses compostos no sangue (KAUR, GUPTA, 2002).

\subsubsection{Aspectos Tecnológicos}

Alguns países, preocupados com o aumento de doenças crônicas não transmissíveis e a transição nutricional, caracterizada pela alta ingestão de gordura e produtos refinados, como açúcar, e reduzida ingestão de fibra alimentar, vem desenvolvendo produtos para dietas especiais, ricos em fibra alimentar, inclusive para dieta enteral (USP, 1998; SÁNCHEZ \& PEREZ, 2001).

No Brasil têm surgido alguns programas de produção de alimentos formulados nos quais se procura substituir, ou reduzir, a proteína de origem animal da dieta, por proteínas de origem vegetal, uma vez que estas apresentam custos mais reduzidos. Os derivados protéicos da soja e do milho têm sido muito usados na suplementação ou em substituição parcial da farinha de trigo, para a obtenção de produtos como pão, biscoito e macarrão (FAZOLIN et al 2007)

A fibra alimentar pode ser utilizada no enriquecimento de produtos ou como ingrediente, pois é constituída de polissacarídeos, lignina, oligossacarídeos resistentes e amido resistente, entre outros, que tem diferentes propriedades físico-químicas. De maneira geral, estas propriedades permitem inúmeras 
aplicações na indústria de alimentos, substituindo gordura ou atuando como agente estabilizante, espessante, emulsificante; desta forma, podem ser aproveitadas na produção de diferentes produtos: bebidas, sopas, molhos, sobremesas, derivados de leite, biscoitos, massas e pães (CHO \& DREHER, 2001).

A industrialização da banana pode representar uma opção no aproveitamento de excedentes de produção e de frutos fora dos padrões de qualidade para consumo in natura, embora sem o comprometimento da qualidade da polpa; a industrialização da banana também promove o aumento da vida-deprateleira e agregação de valor ao produto. Do ponto de vista social, é uma atividade geradora de empregos e renda. O processamento da banana possibilita a obtenção de diferentes produtos, tais como purê, néctar, doce, farinha, passa e outros (CARVALHO \& CARDOSO, 1980). O processamento por desidratação, na obtenção da banana-passa, é simples, envolve poucas operações, requer pouca mão-de-obra e baixo investimento em equipamentos, e pode ser viável em diferentes escalas de produção. A desidratação inibe o crescimento microbiano e minimiza os efeitos de reações químicas, facilitando a estocagem e a distribuição do produto (KAREL, 1974).

O processamento da banana é capaz de gerar modificações substanciais. Num estudo foi avaliado o efeito combinado de alta pressão, temperatura e tempo de tratamento sobre a atividade da polifenoloxidase e da peroxidase da banana. Os autores (MACDONALD \& SCHASCHKE, 2000) concluíram que a redução na atividade da polifenoloxidase foi menos influenciada pelo tratamento combinado do que o da peroxidase, o que poderia ser causado pela solubilização da enzima e ao efeito do conteúdo em sólidos solúveis.

De acordo com Roberfroid (1999) um alimento natural pode ser genuinamente funcional, ou tornar-se funcional pelo aumento de concentração, adição ou substituição de um componente. A obtenção de misturas de farinhas, 
adicionadas de polpa de banana em várias proporções (0-50\%) foram avaliadas por várias características. Os resultados mostraram boa estabilidade de armazenagem de todas as amostras, aumento da gelificação e sua possível aplicabilidade para produtos para forno (OKEZIE et al., 2003). A análise sensorial de suco de fruta, enriquecido com polpa de banana verde cozida, indicaram boa aceitação dentre os panelistas.

A idéia de se produzirem farinhas compostas para uso em panificação e confeitaria não é nova (EERLINGEN 1993). A viabilidade técnica e econômica do uso de farinhas mistas em alimentos também já foi amplamente demonstrada e empregada na indústria (TSEN, 1976). Laguna et al. (2010) adicionaram até um $40 \%$ de AR de milho na farinha de trigo sem detrimento em relação a gosto, doçura e aceitação global de biscoitos.

Misturas de farinha, adicionadas de polpa de banana em várias proporções $(0-50 \%)$ foram avaliadas por várias características. Os resultados mostraram boa estabilidade de armazenamento de todas as amostras, aumento da geleificação e sua possível aplicabilidade para produtos de forno (MASTRO et al., 2007).

O conhecimento das propriedades físico-químicas é importante para a produção de alimentos com boa textura e sabor, porque a simples adição de ingredientes nem sempre resulta em produtos com características sensoriais desejáveis (DREHER,1995). Na prática da clinica nutricional, a viscosidade de dietas enterais, tanto industriais como domésticas, são de estrema importância na administração de sondas determinando a velocidade de escoamento da solução pelo capilar. (ARAUJO \& MENEZES, 2006). 


\subsubsection{Farinha de Banana Verde (FBV)}

A aplicação de AR da banana verde na elaboração de produtos é de interesse, tanto para a indústria de alimentos, como para o consumidor (LAJOLO et al., 2001).

Conforme o Sistema Brasileiro de Respostas Técnicas - SBRT (2006), as farinhas de bananas podem ser obtidas de secagem natural ou artificial, através de bananas verdes ou semiverdes das variedades, Prata, Terra, Cavendish, Nanica ou Nanicão. Quando bem processadas podem ser utilizadas em panificação e alimentos infantis. Sua qualidade depende de vários fatores incluindo matéria-prima, método de secagem, técnicas de procedimentos e forma de armazenamento. Segundo Torres (2005), o método de obtenção da farinha de banana verde pode ser descrito assim:

- Descasca-se a banana de forma manual e corta-se a polpa em rodelas de $3 \mathrm{~mm}$ de espessura, mediante cortador doméstico de frios.

- As rodelas são imersas em solução de 1000 ppm de metabissulfito de sódio, acidificada para pH 3,3 com ácido cítrico.

- A secagem ocorre em estufa com circulação de ar marca FABBE, modelo 170 , sendo as rodelas de banana dispostas em bandejas perfuradas e formando camadas de $12 \mathrm{~mm}$ de espessura. Se mantêm a temperatura de secagem a $66^{\circ} \mathrm{C}$, durante cerca de dez horas até que a umidade final fique próxima de $8 \%$.

- As rodelas de banana seca são desintegradas em moinho de facas Wiley sem peneiras. Passa-se o produto da moagem em jogo vibratório de peneiras com peneira única e malha de 150 micrômetros de abertura. Separa-se a fração que passou pela peneira para ser utilizada em ensaios de extrusão.

- Fasolin et al (2007) avaliaram o aproveitamento de farinha de banana verde na produção de biscoitos cookies nas proporções de 10, 20 e 30\%. Concluíram que alem de elevar o valor nutricional do alimento em fósforo, 
ferro e cálcio o produto teve boa aceitabilidade por parte de consumidores de faixas etárias diferenciadas.

- Ovando-Martinez et al. (2009) utilizaram farinha de banana verde para aumentar a percentagem de carboidratos indigeríveis de massas.

Souza et al. (1999) concluíram que produtos produzidos com farinha de banana podem constituir uma forma alternativa e viável de complemento alimentar seguro e de baixo custo, e serem utilizados como matéria prima para elaboração de outros produtos alternativos de inserção em Políticas de Segurança Alimentar e Nutricional, contribuindo na garantia do Direito Humano à alimentação adequada.

Muyonga et al. (2001) analisaram as mudanças nas propriedades físico-químicas na obtenção de farinha de banana verde. Esses autores mostraram que o tratamento por vapor de água prévio à desidratação criava posteriormente pastas de baixa densidade, maior solubilidade e maior conteúdo de vitamina $\mathrm{C}$, o que é desejável para alimentos para lactantes e suplementos alimentícios.

A composição e as propriedades funcionais da farinha de banana verde obtida por liofilização da polpa de banana verde de 8 diferentes variedades também foi objeto de estudo de pesquisadores brasileiros. Da Mota et al. (2000) concluíram que há diferenças em relação às variedades, mas o resultados podem ser descritos da seguinte maneira: o pico de temperatura de gelificação variou entre 68 e $76^{\circ} \mathrm{C}$ e houve aumento da viscosidade com o esfriamento em todos os casos. Também, o conteúdo de amido ficou entre $61-76,5 \%$, amilose entre $19-23 \%$, proteína entre $2,5-3,3 \%$, umidade $4-6 \%$, lipídeos entre $0,3-0,8 \%$, cinzas $2,6-3,5 \%$ e fibra total $6-15,5 \%$. Os autores ainda sugerem a produção e uso de farinha de banana verde no lugar do amido isolado, por razões econômicas e práticas. 


\subsection{Interação da radiação com a matéria}

Segundo definição do Novo Dicionário Aurélio da Língua Portuguesa a palavra radiação tem duas importantes acepções: (i) qualquer dos processos físicos de emissão e propagação de energia, seja por intermédio de fenômenos ondulatórios, seja por meio de partículas dotadas de energia cinética. (ii) energia que se propaga de um ponto a outro no espaço ou num meio material.

Em particular, a radiação ionizante é a radiação cuja energia é superior à energia de ligação dos elétrons de um átomo com o seu núcleo; radiações cuja energia é suficiente para arrancar elétrons de seus orbitais (NOUAILHETAS et al., 2010)

A interação das radiações ionizantes com a matéria é um processo que se passa em nível atômico. Ao atravessarem um material, estas radiações transferem energia para as partículas que forem encontradas em sua trajetória. Caso a energia transferida seja superior à energia de ligação do elétron com 0 restante da estrutura atômica, este é ejetado de sua órbita. O átomo é momentaneamente transformado em um íon positivo. O elétron arrancado (íon negativo) desloca-se no meio, impulsionado pela energia cinética adquirida neste processo. Esta energia é dissipada através da interação do elétron com elétrons e núcleos de outros átomos, eventualmente encontrados em sua trajetória. Novos íons podem, assim, serem introduzidos na matéria. O processo é interrompido quando, tendo sua energia dissipada em interações (choques), os elétrons (e suas cargas negativas) acabam capturados por moléculas do meio. A introdução de pares de íons (positivo e negativo) na matéria recebe o nome de ionização.

A interação das radiações ionizantes com a matéria consiste na transferência de energia da radiação para o meio irradiado. Ao arrancarem, aleatoriamente, elétrons das camadas eletrônicas de átomos, as radiações ionizantes contribuem para romper, mesmo que momentaneamente, o equilíbrio entre as cargas positivas e negativas do átomo. À introdução de cargas elétricas 
livres em um meio irradiado, segue-se um rearranjo eletrônico que pode envolver elétrons de outros átomos e moléculas. Este rearranjo de elétrons tem como conseqüência o restabelecimento do equilíbrio perdido.

Com exceção dos átomos dos gases nobres, os átomos dos elementos existentes na natureza apresentam a última camada eletrônica incompleta. Esta situação faz com que a estrutura atômica seja instável. Esta instabilidade é contornada através da interação entre diferentes átomos, de modo que cada átomo envolvido no processo tenha, na sua última camada eletrônica, os oito elétrons (ou dois, no caso do átomo de Hidrogênio) que conferem estabilidade à estrutura atômica. Cada elemento possui propriedades químicas que refletem a configuração da última camada eletrônica de seus átomos. Da interação dos átomos surgem as moléculas. Quando um átomo perde elétrons toda a estrutura molecular pode ficar comprometida pelo rearranjo instantâneo de elétrons, na busca de uma configuração mais estável. Esta busca pode resultar numa perda de identidade química para a molécula envolvida e na geração, no sistema irradiado, de moléculas estranhas a ele.

Embora o caráter dualístico da radiação: ora ondulatório, ora corpuscular, podemos simplificar considerando que existem três modalidades de radiações: Radiação alfa ( $\alpha$ ): também chamada de partículas alfa ou raios alfa, são partículas carregadas por dois prótons e dois nêutrons; Radiação beta $(\beta)$ : raios beta ou partículas beta, são partículas negativas que se assemelham aos elétrons, apresenta carga negativa - 1 e massa 0 ; Radiação Gama ( $\mathrm{y}$ ): ou raios gama. O comprimento de onda desta radiação varia de $0,5 \AA$ a $0,005 \AA$ (unidade de medida: angstron). As radiações gama são ondas eletromagnéticas, e possuem carga e massa nulas, emitem continuamente calor $\mathrm{e}$ têm a capacidade de ionizar o ar e torná-lo condutor de corrente elétrica.

Um núcleo radioativo emite radiação alfa ou beta, e a radiação gama está sempre presente. A partícula beta pode atingir uma velocidade de até $95 \%$ 
da velocidade da luz, já a partícula alfa é mais lenta e atinge uma velocidade de $20.000 \mathrm{~km} / \mathrm{s}$, e os raios gama atingem a velocidade das ondas eletromagnéticas $(300.000 \mathrm{~km} / \mathrm{s})$.

Sabe-se que os seres vivos estão expostos de várias maneiras às fontes naturais de radiação ionizante, pois estamos rodeados pelos elementos radioativos naturais da crosta terrestre e bombardeados por raios cósmicos. Também recebemos exposição interna de elementos radioativos através da água e alimentos e pelo ar que respiramos. Além disso, temos o carbono-14, potássio-40, rádio-226 no nosso sangue e ossos que também são elementos radioativos (IAEA, 2003). Por outro lado, estamos expostos externamente aos raios-X da prática médica e da odontologia, detectores de fumaça por meio da ionização, relógios de pulso luminosos, entre outros.

Os raios gama, raios- $X$ ou elétrons acelerados, dependendo da fonte de radiação, têm energia com capacidade de expulsar elétrons de suas órbitas, gerando íons, sendo assim denominadas radiações ionizantes. As possíveis mudanças que podem acontecer em diversos materiais expostos à radiação tem como base a ação dos radicais livres gerados inicialmente. Com freqüência, são os radicais livres gerados nas moléculas de água e na presença de oxigênio os principais responsáveis pelas as mudanças observadas.

Por outro lado, é bom lembrar que existem radiações não-ionizantes, exemplos são microondas, radiação na região ultra-violeta e radiação na região do infravermelho. O nível de energia destas formas de radiação é inferior àquela capaz de produzir a ionização (HAYES et al.1995).

\subsection{Aplicação da radiação ionizante em produtos alimentícios}

Desde tempos remotos, a humanidade tem buscado meios de preservação de alimentos. Métodos como o armazenamento dos alimentos em 
baixas temperaturas está entre as técnicas de preservação mais antigas já conhecidas. A pasteurização, o congelamento rápido, todos desenvolvidos para aplicações comerciais têm sido usadas com alto grau de sucesso. Um dos métodos com grande potencial de aproveitamento na tecnologia de preservação de alimento é o uso da radiação ionizante (HAYES et al.1995).

A quantificação das doses de radiação se faz em função da energia absorvida pelo produto irradiado. A unidade de medida utilizada é o gray (Gy) ou quilogray (kGy) e um Gray equivale a um Joule de energia por quilograma de alimento irradiado.

A dose de irradiação a ser dada ao alimento é determinada pelo efeito desejado: altas doses, maiores que 10kGy, são destinadas para a esterilização de alimentos; doses médias, de 1 a 10 kGy, exercem um efeito de pasteurização aumentando a vida de prateleira; e baixas doses, menores de 1kGy, controlam efetivamente a infestação por parasitas e insetos, e diminuem o processo de senescência na maioria das frutas frescas e o brotamento de vegetais (ANDREWS et al., 1998). Porém, na pratica, a dose máxima é estabelecida tendo como base 0 aparecimento de mudanças indesejáveis nas características sensoriais (KILCAST, 1991).

Dependendo da dosagem de radiação ionizante, pode-se chamar o processo de radapertização, radiciação ou radurização. A radapertização ou esterilização é o tratamento do alimento com uma dose de energia ionizante suficiente para prevenir a decomposição e a toxidez de origem microbiana, seja quais forem o tempo e as condições de armazenamento do produto, desde que este não seja contaminado novamente. As doses requeridas nesse processo geralmente estão entre 25 a 45 kGy (OMS, 1995; SATIN, 1997). Esta técnica é muito empregada para produtos cárneos. 
A radiciação é o tratamento do alimento com uma dose de energia ionizante suficiente para reduzir o número de bactérias patogênicas viáveis e não produtoras de esporos, de forma que não sejam detectadas por métodos de análises bacteriológicas nos alimentos tratados. Esse tratamento também inativa parasitas presentes nos alimentos. As doses requeridas nesse processo geralmente estão entre 2 a 8 kGy (OMS, 1995; SATIN, 1997). A radiciação é utilizada na pasteurização de sucos, carnes frescas, massas frescas etc.

A radurização pode ser encarada como tratamento semelhante à pasteurização, causa a redução na contagem de microorganismos deterioradores viáveis. Neste caso geralmente utilizamos outros métodos de conservação associados, como a refrigeração. As doses utilizadas se encontram na faixa entre 0,4 a 2,5 kGy. A radurizacao pode ser utilizada para prevenir brotamentos em bulbos e tubérculos, retardar o tempo de maturação de frutas, prevenir a deterioração por fungos em frutas e hortaliças e controle de infestação por insetos, ácaros etc.

Em relação aos aspectos químicos da interação da radiação ionizante com as macromoléculas que constituem os alimentos, é possível obter degradação ou despolimerização, com diminuição da massa molecular ou agregação/polimerização resultante de novas ligações inter ou intra-moleculares, com aumento da massa molecular.

O processamento por radiação ionizante nas condições recomendadas pelo Codex Alimentarius e adotado pela legislação brasileira (BRASIL, 2001) não aumenta o nível normal de radioatividade do alimento, independentemente do seu tempo de exposição à radiação ou o quanto é absorvido de uma dose de energia. Quanto maior a exposição dos produtos aos raios gama, maior a dose absorvida. No caso de irradiação com feixe de elétrons, quanto mais vagarosamente o 
produto é movido sob os feixes de elétrons ou raios-X, maior será a dose resultante.

A irradiação de alimentos é uma tecnologia que pode ser utilizada com segurança no controle dos mais sérios problemas relacionados com os alimentos: as perdas provenientes da deterioração e as doenças que podem ser ocasionadas pelo consumo de alimentos contaminados por microorganismos patogênicos. Por outro lado, pela sua capacidade de eliminar insetos e outras pragas, a irradiação oferece uma importante alternativa ao uso de produtos químicos como meio de atender os requerimentos quarentenários para a desinfestação de commodities para o comércio internacional.

Em 1981, um comitê conjunto de especialistas em Salubridade de Alimentos Irradiados da Organização das Nações Unidas para a Agricultura e Alimentação (FAO), da Agência Internacional de Energia Atômica (IAEA) e da Organização das Nações Unidas (WHO) concluiu que a irradiação de qualquer produto alimentício com dose média total de até 10 kGy não oferecia qualquer risco toxicológico ou problema de ordem microbiológica ou nutricional. Relatório de especialistas convocados pelas FAO/IAEA/WHO para estudar o efeito de altas doses de irradiação, concluiu que alimentos irradiados com doses acima de 10 kGy não causam nenhum risco de saúde para os consumidores (WHO, 1999). O Grupo Consultivo Internacional sobre Irradiação de Alimentos (ICGFI) foi criado em 1984, para estudar o tema e registrar os avanços, benefícios e a segurança dos alimentos tratados por irradiação ionizante. Foi um grupo de estudo conjunto da Organização das Nações Unidas para Agricultura e Alimentos (FAO), da Organização Mundial de Saúde (WHO), e da Agência Internacional de Energia Atômica (IAEA) encerrado em 2001. Uma das tarefas do ICGFI, órgão multigovernamental que contou com 46 países membros, o Brasil dentre eles, era a de compilar informações sobre a utilização segura e apropriada da tecnologia de irradiação aos países membros. 
O tratamento por irradiação, como mencionado acima, é uma das alternativas de conservação de alimentos, já que não afeta de maneira adversa a qualidade do alimento. A história da irradiação de alimentos surgiu pouco depois do descobrimento da radioatividade e dos raios $X$, no final do século XIX, quando foi percebido que a radiação poderia ser aplicada para matar bactérias e retardar a germinação e amadurecimento de frutas e vegetais. A possibilidade do uso da irradiação, para prolongar o tempo de vida de certos alimentos, se tornou uma proposta prática a partir dos anos 50 , quando começaram a ser construídas instalações industriais de irradiação de grande porte. No Brasil a aplicação de radiação ionizante em produtos alimentícios começa na década de 1980 e até hoje se restringe praticamente a especiarias e produtos vegetais desidratados (MASTRO, 1999a).

A radiação só pode acentuar as qualidades do alimento, que se já estiver deteriorado não poderá ser melhorado com esse processo.

É importante salientar que para cada aplicação específica da radiação em alimentos existe uma faixa de dose adequada recomendada pelos especialistas com base nos estudos publicados na literatura (OLSON, 1995). O conceito de dose de radiação é dado pela quantidade de energia absorvida pelo alimento quando passa através do campo de radiação durante o processamento.

A radiação afeta os alimentos de diferentes formas, dependendo da dose, das condições de irradiação e da composição dos alimentos. A maioria dos efeitos da radiação na qualidade dos alimentos está relacionada à formação de radicais pela ionização do oxigênio, água e moléculas de lipídeos nos alimentos (HAYES et al.1995).

O impacto da irradiação sobre os nutrientes tem sido motivo de muitas pesquisas na área de alimentos. Foi observado, entretanto, que as alterações advindas são as mesmas que as originadas pela aplicação de outros processos 
empregados na conservação de alimentos, principalmente no que se refere a oxidação de lipídios, formação de radicais livres, etc. Contudo, na irradiação essas alterações podem ser minimizadas, simplesmente pela mudança das condições de processo, como, por exemplo, o emprego de embalagens com atmosfera modificada (MAP) e redução da temperatura. Por isso, o valor nutricional dos alimentos não é significativamente afetado pela irradiação. Macronutrientes, como as proteínas, são relativamente estáveis, quando os alimentos são expostos à dose máxima de irradiação de 10kGy (1Mrad ou $1000000 \mathrm{rad}$ ) (NARVAIZ, \& LADOMERY,1988, OMS,1981). Os micronutrientes, em especial as vitaminas, podem sofrer redução em pequenas proporções pelo emprego de irradiação. A sensibilidade das vitaminas ao processo é variada, dependendo das condições nas quais se irradiam os alimentos. As vitaminas $\mathrm{C}$ e B1 são as mais sensíveis no grupo das hidrossolúveis e, as vitaminas $E$ e $A$ as mais sensíveis no grupo das lipossolúveis (KILCAST, 1994)

Entre 1964 e 1997, a Organização Mundial de Saúde acompanhou os resultados de estudos com alimentos irradiados, em conjunto com Organização das Nações Unidas para Agricultura e Alimentação (FAO) e a Agência Internacional de Energia Atômica (IAEA), com base em uma série de reuniões com especialistas de diversos países do mundo. Na reunião de setembro de 1997, a conclusão final divulgada foi: a OMS aprova e recomenda a irradiação de alimentos, em doses que não comprometam suas características organolépticas, sem a necessidade de testes toxicológicos. A partir disto, a irradiação de determinados alimentos e ingredientes para alimentos foi aprovada pelas autoridades de saúde em aproximadamente 60 países (DELINCÉE, 1998). Os alimentos que foram tratados por irradiação devem estar corretamente embalados e etiquetados para indicar que, a este produto, foi aplicado este processo. Devem ser utilizados os termos "irradiado" ou "tratado por radiação ionizante" (CAC, 2003). Na TAB 4 estão resumidas as aplicações da irradiação de alimentos. 
Atualmente, especiarias estão sendo irradiadas comercialmente, evitando a fumigação, em muitos países incluindo a Argentina, Bélgica, Brasil, Canadá, China, Dinamarca, Finlândia, França, Hungria, Indonésia, Israel, México, Holanda, Noruega, República da Coréia, África do Sul, Reino Unido e EUA (TAMIKAZU et al., 2009).

A aplicação mais importante desse método de preservação de alimentos talvez seja assegurar a qualidade higiênica de alimentos sólidos e semisólidos, especialmente os de origem animal, através da inativação de patógenos transmitidos no alimento. Esta aplicação pode ser comparada à pasteurização a quente dos alimentos líquidos, por exemplo, leite, que é efetiva e muito aplicada, porém inadequada para alimentos como aves, carnes e frutos do mar que devem ser comercializados em estado natural.

Tabela 4. Aplicações da irradiação de alimentos

\begin{tabular}{|c|c|c|}
\hline Beneficio & $\begin{array}{l}\text { Dose } \\
\text { (kGy) }\end{array}$ & Produtos \\
\hline \multicolumn{3}{|l|}{ Dose baixa (até 1kGy). } \\
\hline (1) inibição do brotamento & $\begin{array}{c}0,05- \\
0,15\end{array}$ & $\begin{array}{l}\text { Batatas, cebolas, alho, ralz de } \\
\text { gengibre, inhame. }\end{array}$ \\
\hline $\begin{array}{l}\text { (ii) desinfestacăo de insetos e } \\
\text { desinfecçä́o de parasitas }\end{array}$ & $0,15-0,5$ & $\begin{array}{l}\text { Cereais e grăos de leguminosas, } \\
\text { frutas frescas e secas, peixe e } \\
\text { carne seca, carne de porco fresca. }\end{array}$ \\
\hline $\begin{array}{l}\text { (iii) Atraso em processos } \\
\text { fisiológicos (por exemplo: } \\
\text { maturacăg). }\end{array}$ & $0,25-1,0$ & Frutas e legumes frescos. \\
\hline \multicolumn{3}{|l|}{ Dose média (1 - $10 \mathrm{kGy})$} \\
\hline $\begin{array}{l}\text { (0) Extensảo do tempo de } \\
\text { prateleira }\end{array}$ & $1.0-3.0$ & $\begin{array}{l}\text { Peixe fresco, morangos, } \\
\text { cogumelos. }\end{array}$ \\
\hline $\begin{array}{l}\text { (ii) Eliminação de } \\
\text { microorganismos da } \\
\text { deterioraçấo e patogênicos }\end{array}$ & $1,0-7,0$ & $\begin{array}{l}\text { Frutos do mar frescos e } \\
\text { congelados, aves e carnes frescas } \\
\text { ou congeladas. }\end{array}$ \\
\hline $\begin{array}{l}\text { (iii) Melhora das propriedades } \\
\text { tecnológicas do alimento }\end{array}$ & $2,0-7,0$ & $\begin{array}{l}\text { Uvas (aumento do rendimento do } \\
\text { suco), legumes desidratados } \\
\text { (reduçấo do tempo de cozimento). }\end{array}$ \\
\hline \multicolumn{3}{|l|}{ Dose alta (10 - 50 kGy) } \\
\hline $\begin{array}{l}\text { (1) Esterilizaçấo industrial (em } \\
\text { combinaçấo com calor } \\
\text { moderado) }\end{array}$ & $30-50$ & $\begin{array}{l}\text { Cames, aves, frutos do mar, } \\
\text { alimentos preparados, dietas } \\
\text { esterilizadas de hospital. }\end{array}$ \\
\hline $\begin{array}{l}\text { (ii) Descontaminação de certos } \\
\text { aditivos e ingredientes de } \\
\text { alimentos }\end{array}$ & $10-50$ & $\begin{array}{l}\text { Especiarias, preparaçốes de } \\
\text { enzimas, goma natural. }\end{array}$ \\
\hline
\end{tabular}

Fonte - ICGFI, 1999] 
A irradiação de alimentos é uma tecnologia promissora que pode contribuir para a segurança de abastecimento de alimentos e que oferece algumas vantagens sobre outros métodos de preservação de alimentos. Em muitos casos, com a irradiação os produtos estão em uma posição mais desejável do que os não irradiados: o produto pode ser irradiado depois de embalado, eliminando qualquer tipo de contaminação posterior que poderia ocorrer. Também, a irradiação oferece um ponto crítico de controle para o consumidor. No caso de falha para alcançar a temperatura interna específica durante o cozimento do produto, a irradiação é uma garantia para o consumidor porquanto as bactérias contaminantes seriam preventivamente eliminadas pela irradiação (HAYES et al.1995).

Alimentos esterilizados por radiação, utilizando doses acima de 25 kGy, podem ser dados a pacientes com deficiência do sistema imunológico, que requerem dieta estéril (MASTRO, 1999b). Produtos radio-esterilizados são consumidos por astronautas nos programas espaciais da NASA devido à sua qualidade superior, segurança e variedade, comparados a alimentos tratados por outras técnicas de preservação.

Os alimentos em geral contêm alguns componentes-chaves que, embora presentes em concentrações muito baixas, regulam o sabor, aspecto e valor nutritivo (WHO, 1994). Esses componentes são muito sensíveis à irradiação e, se a dose de radiação for alta, pode causar transformações prejudiciais no sabor, odor e cor desses alimentos (DELINCÉE, 1998). Em geral, o processo de irradiação nas doses recomendadas, acarreta poucas alterações químicas nos alimentos. Segundo Diehl (1992; 1995), com doses de até 1,0 kGy, as perdas nutricionais são consideradas insignificantes e nenhuma das alterações conhecidas encontradas nos alimentos irradiados é nociva ou perigosa, estando dentro dos limites encontrados normalmente para alimentos (DELINCÉE, 1998). As perdas são menores quando o tratamento pela radiação é conjugado com 
baixa temperatura e vácuo, podendo-se assim, aumentar as doses de radiação, sem prejuízo do valor nutricional do alimento (DIEHL, 1992). Pesquisas demonstraram que macronutrientes tais como proteínas, são relativamente estáveis a doses de até 10 kGy, e que os micronutrientes, principalmente as vitaminas, podem ser sensíveis a qualquer método de tratamento de alimentos (DIEHL, 1992).

Mudança na textura por quebra de carboidratos é um dos principais determinantes da dose a ser empregada na irradiação de vegetais. A degradação de carboidratos como celulose, pectina e amido leva ao amolecimento, que geralmente não é desejável (URBAIN, 1986; KILCAST, 1991) Tal degradação pode enfraquecer a rígida estrutura dos tecidos ou alterar paredes celulares reduzindo o turgor. E ainda, mudanças nos tecidos podem liberar enzimas endógenas em locais em que irão atacar os carboidratos, ou as mudanças nos carboidratos pode torná-los mais susceptíveis ao ataque enzimático (KILCAST, 1991). Entretanto, alguns efeitos podem vir a ser benéficos e adequados para o posterior uso na indústria de alimentos.

Nenhuma prática ou atividade humana está totalmente desprovida de riscos. Por isso, a tecnologia por radiação pode ser vista de uma perspectiva de que o benefício que ela pode acarretar para a humanidade é grande e com menos riscos do que muitos outros agentes (IAEA, 2003).

\subsection{Legislação sobre alimentos irradiados}

O País possui legislação sobre alimentos irradiados apenas no âmbito do Ministério da Saúde, embora a fiscalização de produtos alimentícios para comércio externo, por exemplo, esteja a cargo do outros ministérios.

No Brasil, a legislação para alimentos irradiados, incluindo os decretos e resoluções são apresentados de forma resumida a seguir: 
Decreto-lei ㄲo. 986 de 21 de outubro de 1969. Estabelece normas gerais sobre alimentos. Inícios da Legislação brasileira sobre irradiação de Alimentos.

Decreto №. 72.718 de 29 de Agosto de 1973. Estabelece normas gerais para processamento. Estocagem, transporte, importação e exportação, venda e consumo de alimentos irradiados. Estabelece o logo da Radura no rótulo de produtos irradiados.

Portaria DINAL № 09 de 08 de março de 1985 (MS) aprova normas gerais para a irradiação de alimentos no Brasil, indicando para cada caso o tipo, nível e dose média de energia de radiação e o tratamento prévio conjunto ou posterior. Limitada a dose de $10 \mathrm{kGy}$ e proibida a re-irradiação. Ampliação da autorização a outros tipos de alimentos que não constavam na portaria anterior.

Portaria DINAL no 30 de 25 de setembro de 1989 Amplia a autorização a outros tipos de alimentos que não constavam de portaria anterior.

Resolução ANVISA - RDC ㄲo. 21 de 26 de janeiro de 2001. Revoga as Portarias DINAL no. 09 de 08 de Março de 1985 e no. 30 de 25 de setembro de 1989.

As radiações permitidas para aplicação em alimentos são:

- Raios gama de ${ }^{60} \mathrm{Co}\left(\mathrm{T}_{1 / 2}: 5,263\right.$ anos; $\beta^{-}: 0,314 \mathrm{MeV} ; \gamma: 1,173 \mathrm{e}$ $1,332 \mathrm{MeV}) \mathrm{e}$

- Raios gama de ${ }^{137} \mathrm{Cs}\left(\mathrm{T}_{1 / 2}: 30\right.$ anos; $\beta-0,514$ e $1,176 \mathrm{MeV}$, que decai a $\left.{ }^{137 \mathrm{~m}} \mathrm{Ba}, \mathrm{T}_{1 / 2:} 2,554 \mathrm{~min} . ; \gamma: 0,662 \mathrm{MeV}\right)$;

- Feixe de elétrons de até $10 \mathrm{MeV}$;

- Raios X de até $5 \mathrm{MeV}$. 
$\mathrm{Na}$ atual legislação brasileira do Ministério da Saúde (Brasil, 2001), que deixou sem efeito as portarias anteriores, não há restrições em relação às doses a serem aplicadas, não mais vigorando a lista restrita de alimentos autorizados para serem irradiados que constavam das Portarias: 9 de 8-3-1985 e 30 de 25-91989 do Ministério da Saúde. No texto da resolução hoje em vigor, fica estabelecido que:

a) "a dose mínima absorvida deve ser suficiente para alcançar a finalidade pretendida";

b) "a dose máxima absorvida deve ser inferior àquela que comprometeria as propriedades funcionais e ou os atributos sensoriais do alimento".

Cabe destacar a abrangência da legislação do Brasil nesta matéria, uma vez que a maioria dos países proíbe, não tem legislação sobre alimentos irradiados, ou permite apenas a irradiação de alguns produtos.

\subsection{Viscosidade}

\subsubsection{Definição}

A viscosidade faz parte da reologia e pode ser definida como o estudo da mudança na forma e no fluir da matéria, abrangendo a elasticidade, viscosidade e plasticidade. A viscosidade, por sua vez, é definida como o atrito interno do fluido, causado pela interação entre as moléculas, os quais ocasionam uma resistência no sentido do escoamento do fluido. Esse atrito se torna aparente quando uma camada do fluido é movida em relação à outra.

Um fluido é uma substância que se deforma continuamente quando submetida a uma tensão de cisalhamento, não importando o quanto pequena possa ser essa tensão (STREETER, 1974). E quanto maior o atrito, maior a força 
requerida para ocorrer o movimento, o qual é chamado de deformação. Nos fluidos todas as deformações envolvem algum tipo de escoamento o que torna seus efeitos totalmente irreversíveis, salvo nos casos de fluidos viscoelásticos onde parte da deformação pode ser recuperada (NAVARRO, 1997).

As propriedades mais importantes nos cálculos de escoamento de fluidos são a viscosidade e a massa específica; elas têm fundamental importância nos escoamentos laminar e turbulento (STREETER, 1974). E a viscosidade é uma propriedade determinante para usos e aplicações dos materiais fluidos. Além de ser uma medida direta da qualidade do fluido em uso, a viscosidade pode fornecer importantes informações sobre mudanças fundamentais em sua estrutura durante um determinado processo, como por exemplo: polimerização, emulsificação e homogeneização (NAVARRO, 1997).

Sendo uma variável controladora de processo, torna-se imperioso o estudo dos efeitos da temperatura, pressão, composição, peso molecular entre outras quantidades físicas e físico-químicas sobre a viscosidade, para que estas possam ser, por exemplo, monitoradas a partir de medições de viscosidade.

A viscosidade do gás aumenta com a temperatura, pois aumenta os choques entre as moléculas, mas a viscosidade do líquido diminui, pois esse aumento de temperatura enfraquece a interação entre as moléculas. A variação com a temperatura pode ser explicada examinando-se o mecanismo da viscosidade. A resistência de um fluido ao cisalhamento depende da coesão e da velocidade de transferência de quantidade de movimento molecular. A coesão parece ser a causa predominante da viscosidade em um líquido e como a coesão diminui com a temperatura, a viscosidade segue o mesmo comportamento (STREETER, 1974). Com relação à pressão do líquido, a viscosidade permanece constante, considerando um fluido incompressível e no caso dos gases, a viscosidade permanece constante com aumento de pressão para gases ideais; para gases reais a variação é muito pouca e portanto, constante. 
Isaac Newton definiu a viscosidade considerando 0 modelo representado por duas placas planas paralelas de mesma área $A$, que estão separados por uma distância $d x$. A placa inferior é fixa e uma força $F$ é aplicada na placa superior, a qual exerce uma tensão de cisalhamento F/A na substância. Newton assumiu que a força requerida para manter essa diferença de velocidade era proporcional à diferença de velocidade através do líquido ou gradiente de velocidade (DZIEZAK, 1991). Para expressar isso, foi descrito:

$$
\frac{F}{A}=\eta \frac{d v}{d x}
$$

Onde $\eta$ é uma constante de um dado material chamado de viscosidade.

O gradiente de velocidade, $\mathrm{dv} / \mathrm{dx}$ é uma medida de velocidade que as camadas intermediárias escoam entre elas. Isso descreve a deformação do líquido, chamado de taxa de deformação, simbolizado como $\mathrm{S}$ em uma discussão subseqüente, com unidade (s-1). O termo F/A indica força por unidade de área requerida para produzir a ação de deformação. Isso pode ser referido como tensão de cisalhamento e será simbolizado por F', com uma unidade de medida de dynes/cm2.

Usando um termo simplificado, a viscosidade pode ser definida matematicamente pela fórmula:

$$
\eta=\text { viscosidade }=\frac{F^{\prime}}{S}=\frac{\text { tensão de cisalhamento }}{\text { taxa de deformação }}
$$

A unidade fundamental de medida de viscosidade é "poise" ( $p$ ). Porém a unidade do Sistema Internacional e de designações Métricas é expressa por "pascal-segundos" (Pa.s) ou (mPa.s), sendo que 1 Pa.s é igual a 10 p; 1 mPa.s é igual a $1 \mathrm{cp}$. 


\subsubsection{Fluidos newtonianos}

O tipo de comportamento de escoamento que Newton assumiu para todos os fluidos, incompressíveis, foi "Newtoniano". Entretanto, é um dos vários tipos de comportamentos que se pode encontrar. Um fluido newtoniano pode ser representado graficamente na FIG 1. A figura abaixo mostra que a viscosidade do fluido permanece constante com a variação da taxa de deformação (DZIEZAK, 1991).

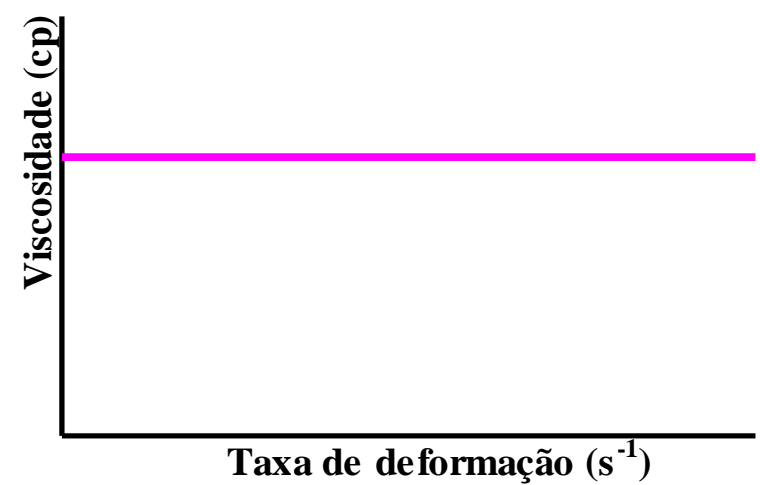

Figura 1. Exemplo de fluido newtoniano.

\subsubsection{Fluidos não-newtonianos}

O fluido não-newtoniano foi definido de modo geral como o qual a relação F'/S não é constante, ou seja, quando a taxa de deformação é variada, tensão de cisalhamento não varia na mesma proporção (DZIEZAK, 1991). A viscosidade desses fluidos vai variar de acordo com a taxa de deformação. O escoamento não-newtoniano é provavelmente uma questão mecânica. Como os objetos assimétricos passam entre eles, e como ocorre durante o escoamento, seu tamanho, forma e coesividade vão determinar o quanto de força é necessário para movê-los.

Há uma variedade de comportamento de escoamento de fluidos não-newtonianos caracterizados pelo modo como a viscosidade do fluido varia em relação à taxa de deformação. Os tipos de fluidos não-newtonianos mais comuns 
são: o pseudoplástico, que exibe um decréscimo na viscosidade com o aumento da taxa de deformação, como mostrado na FIG 2, dilatante, onde a viscosidade aumenta com o aumento da taxa de deformação e o plástico, onde o fluido se comporta como um sólido sob condições estáticas.

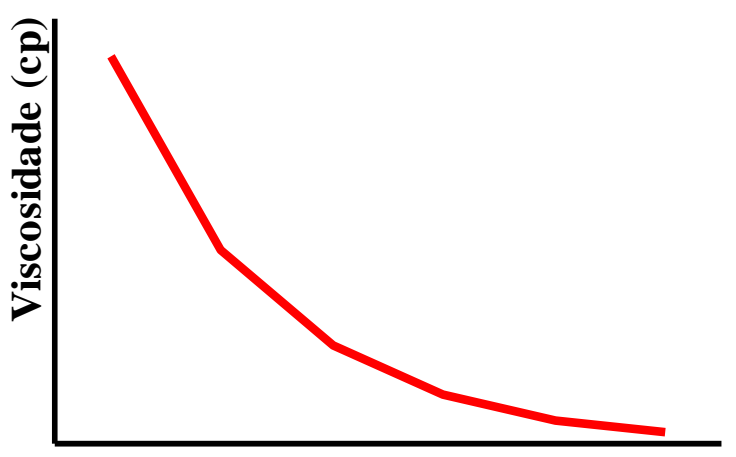

Taxa de deformação $\left(s^{-1}\right)$

Figura 2. Exemplo de fluido não-newtoniano pseudoplástico

\subsection{Textura}

A textura do alimento é o grupo de características físicas que são sentidas. As características de textura podem ser apresentadas em três grupos principais:

- características mecânicas;

- características geométricas;

- outras características referentes à umidade e teor de gordura.

As características mecânicas são manifestadas pela reação do alimento a uma força aplicada e podem ser divididas de acordo com os seguintes parâmetros (MEDEIROS \& LANNES, 2000; LANNES, 1997; DUTCOSKY,1996):

- Dureza - força necessária para atingir uma deformação;

- Coesividade - resistência das ligações internas que formam o produto;

- Viscosidade - taxa de fluxo por unidade de força; 
- Elasticidade - taxa na qual o material deformado volta a sua posição inicial após a força ser removida;

- Adesividade - força necessária para superar a atração entre a superfície do alimento e a de outros materiais com o qual ele tem contato;

Parâmetros secundários:

- Fraturabilidade - Relacionado aos parâmetros primários de dureza e coesividade, é a força que aplicada ao material causa a fratura;

- Mastigabilidade - energia requerida para mastigar um elemento sólido até a sua deglutição. Esta relacionada aos parâmetros primários de dureza, coesividade e elasticidade;

- Gomosidade - energia requerida para desintegrar um alimento semi-sólido até a deglutição. Está relacionado com os parâmetros primários de dureza e coesividade.

A textura de um alimento ou bebida tem influência na aceitação do produto e pode ser vista como parâmetro para controle de qualidade, estando relacionada com a densidade, viscosidade, tensão superficial, dureza e outras propriedades físicas do produto (GUINARD \& MAZZUCCHELLI, 1996). A textura de um alimento sofre influência dos ingredientes escolhidos para a formulação do produto e do processo de produção (DECKER \& ZIEGLER, 2002).

A percepção dos atributos de textura é difícil de predizer, devido às constantes mudanças que o produto sofre quando em contato com a boca, no entanto atributos como a dureza tem boa correlação entre resultados instrumentais e sensoriais (GUINARD \& MAZZUCCHELLI, 1996; NATTRES, 2004).

A maneira mais usual aplicada em medidas de textura instrumental é através do contato direto entre o probe do equipamento e a amostra, que sofre uma deformação. A extensão da deformação ou resistência oferecida pela amostra é o parâmetro utilizado como índice de textura do alimento. 


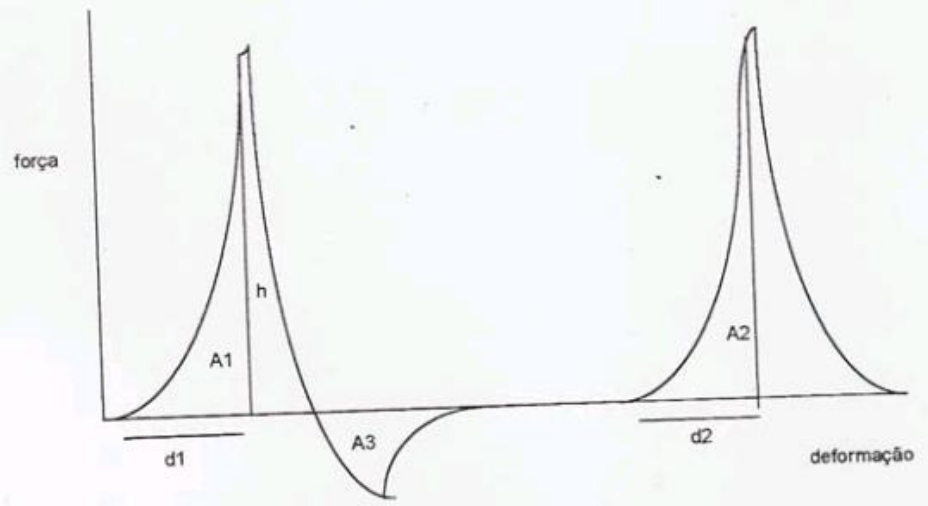

Figura 3 - Curva típica do perfil de textura (Lannes, 1997)

A FIG 3 mostra curva típica de um perfil de textura. Onde pode ser observada a deformação do material quando submetido a determinada força. Os valores A1, A2 e A3 são as áreas sob a curva, d1 e d2 as distâncias de compressão. O valor de h, para a distância d1, determina a dureza do material. 


\section{MATERIAL E MÉTODOS}

\subsection{Material}

Uma parte das amostras de farinha de banana verde (lote 012) foi cedida pela Nutracêutica Produtos Naturais Ltda CNPJ 031410550/0001-77 de Nova Lima, MG. Outra parte foi adquirida a granel no comércio popular da zona cerealista em São Paulo. As amostras das farinhas foram embaladas em filme plástico de poli-cloreto de vinila (PVC) próprio para alimentos, onde foram identificadas como farinha de banana verde 1 (FBV1) e farinha de banana verde 2 (FBV2).

\subsection{Irradiações}

As amostras acondicionadas em sacos de polipropileno próprio para alimentos. Foram irradiadas no Centro de Tecnologia das Radiações (CTR), Instituto de Pesquisas Energéticas e Nucleares (IPEN/CNEN-SP), em fonte de cobalto-60 Gammacell 220 da Atomic Energy of Canada Ltd (AECL) com doses de 1, 3, 5, e $10 \mathrm{kGy}$, taxa de dose $~ 2 \mathrm{kGy} / \mathrm{h}$. A dosimetria foi realizada utilizando dosímetro Amber 3042 Batch S-603 nm. As doses foram escolhidas dentro do âmbito de doses aplicadas em alimentos, isto é, doses baixas, até 1kGy, doses médias, até 10kGy.

\subsection{Viscosimetria}

As medidas viscosimétricas foram realizadas no CTR-IPEN-CNEN/SP, utilizando o viscosímetro Brooksfield, modelo DVIII, com adaptador para pequenas amostras ULA (ultra low adaptador), utilizando spindles adequados, em banho termostatizado Neslab modelo RTE-210, precisão $\pm 0,1^{\circ} \mathrm{C}$ (FIG.4). O viscosímetro fornece para cada valor de velocidade do spindle, a viscosidade aparente, a força e a taxa de cisalhamento para cada valor da temperatura, mediante o processador de dados Rhecalc software. Os efeitos da radiação foram medidos em amostras irradiadas a 0, 1 e 3 kGy. As amostras para os ensaios viscosimétricos consistiram em soluções a $3 \%$ e $5 \%$ em água destilada em porções de $50 \mathrm{ml}$, a temperatura de $70 \stackrel{\circ}{ } \mathrm{C}$. Os spindles utilizados foram T-A, SC4- 
18 e SC4-31. Devido a características diferentes dos géis produzidos pelas FBV1 e FBV2, somente foi possível medir a viscosidade da FBV1.

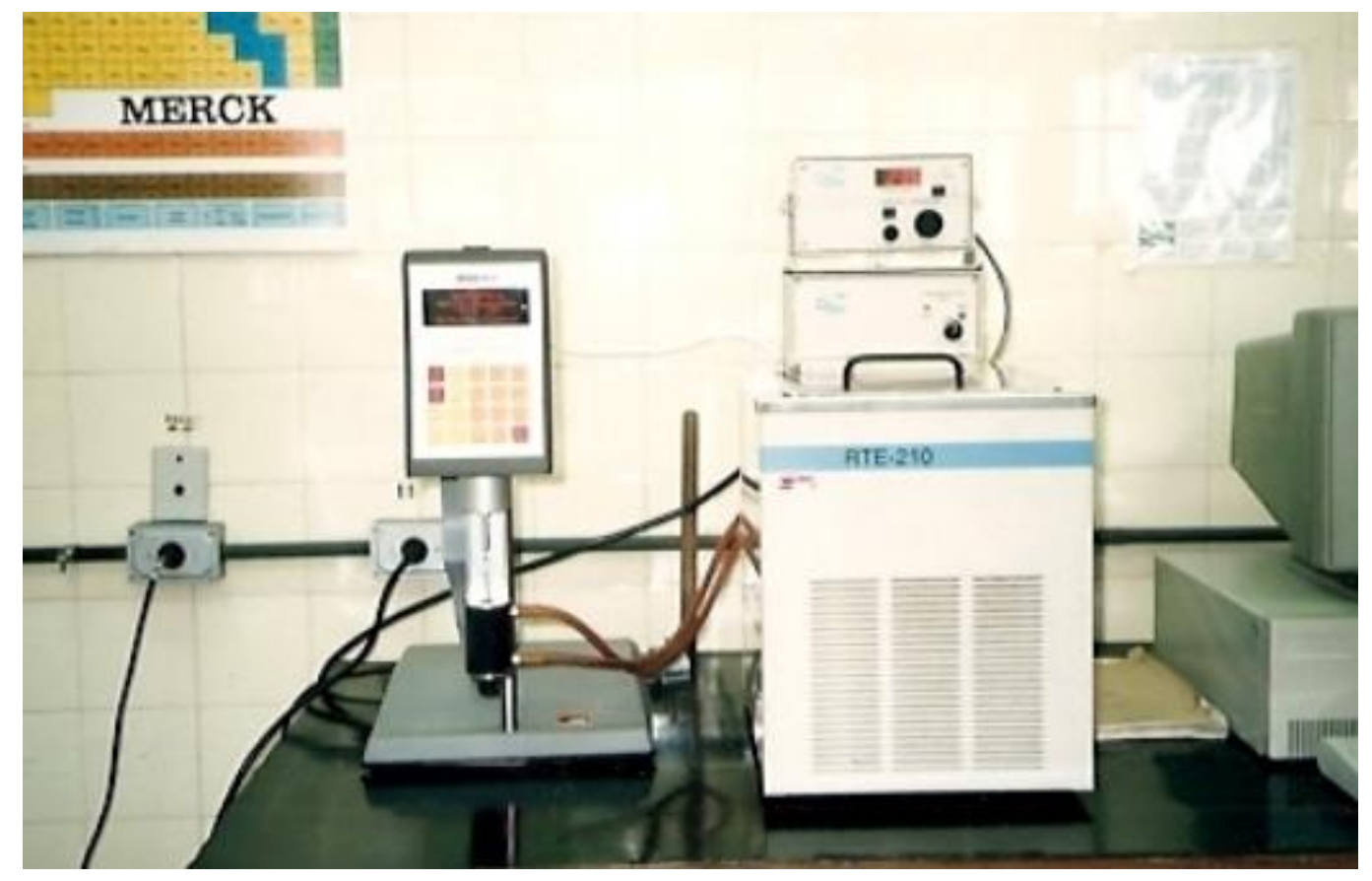

Figura 4. Viscosímetro Brooksfield, modelo DVIII

\subsection{Análise de Textura}

A textura foi analisada utilizando o texturômetro TA-XT2 da marca Stable Micro Systems (FIG. 5), operando com software Texture Expert, No Instituto de Desenvolvimento de Panificação e Confeitaria (IDPC), com modo e operação de força de compressão, com velocidade de teste de $50 \mathrm{~mm} / \mathrm{s}$. Utilizouse um corpo de prova P36R, que foi aplicado no centro Da amostra. O parâmetro avaliado foi à força máxima de ruptura, obtido por meio do registro da curva força $x$ tempo. Foram avaliadas as amostras de farinha de banana verde irradiadas a 0 ; 1; 3; 5 e 10 kGy, diluídas a 9\% em água destilada, e armazenadas em recipiente de PVC com tampa, próprio para alimentos, com capacidade para $145 \mathrm{ml}$. Após o preparo as amostras foram armazenadas sob refrigeração por $24 \mathrm{~h}$, chegando a temperatura média de $7 \stackrel{\circ}{ } \mathrm{C}$. As amostras foram retiradas da refrigeração e 
realizadas as análises imediatamente. Foram medidas em torno de 20 amostras de cada tratamento. As medidas foram realizadas em triplicata.

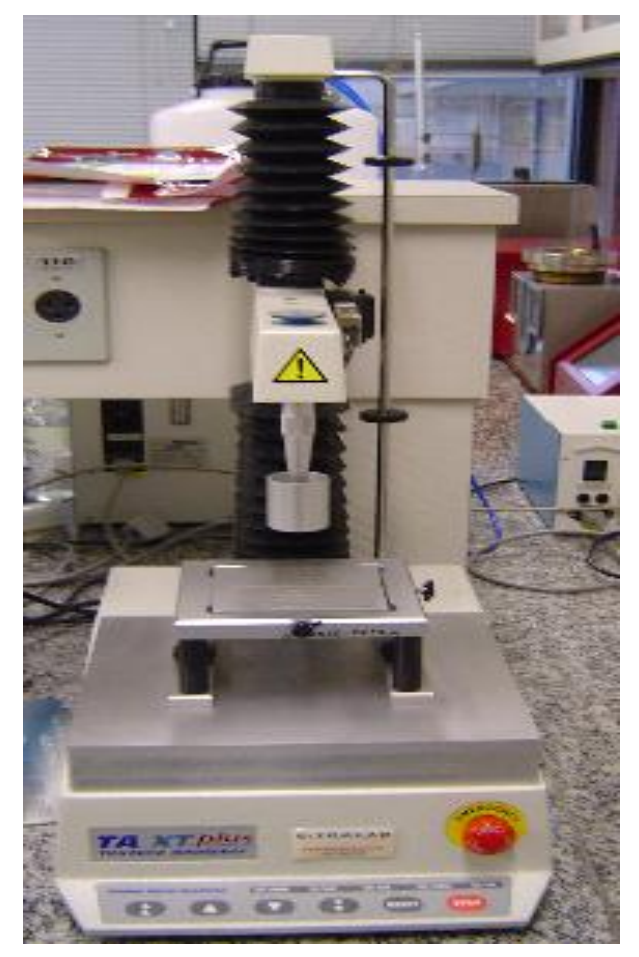

Figura 5. Texturômetro TA-XT2 da marca Stable Micro Systems utilizado nos ensaios.

\subsection{Colorimetria}

Para a realização da análise instrumental da cor das FBV1 e FBV2, foi utilizado o colorímetro Minolta Chroma Meter modelo CR200b, com a configuração $L^{*}{ }^{*}$, sendo $L$ : luminosidade. $L^{*} a^{*} b^{*}$, porém são empregadas coordenadas cilíndricas ao invés de coordenadas retangulares.

Antes de iniciar o experimento foi necessário calibrar o equipamento com o "branco". Para isto, foi posicionado o aparelho sobre este "quadrado branco" e pressionada a tecla enter do computador ligado ao equipamento. Após a calibração, as farinhas foram analisadas. Quarenta medidas foram realizadas para cada tipo de farinha e dose de irradiação. $O$ aparelho foi posicionado no de forma vertical e em regiões aleatórias. Este procedimento foi repetido para todos 
as amostras analisadas. O equipamento precisa de uma referência, ou seja, um padrão para fornecer resultados coerentes; no caso as farinhas do grupo controle (OkGy) foram utilizados como padrão, para ser comparado com os demais tratamentos.

\subsection{Fração sol - gel}

Esta determinação foi realizada com a FBV1 não irradiada e irradiada a 3kGy. Foi preparado um hidrogel com água destilada e 40\% de FBV1. As amostras foram lavadas com água purificada em extrator Soxhlet (FIG. 6) por 12 horas. Em seguida as amostras foram levadas a estufa até atingirem peso constante.

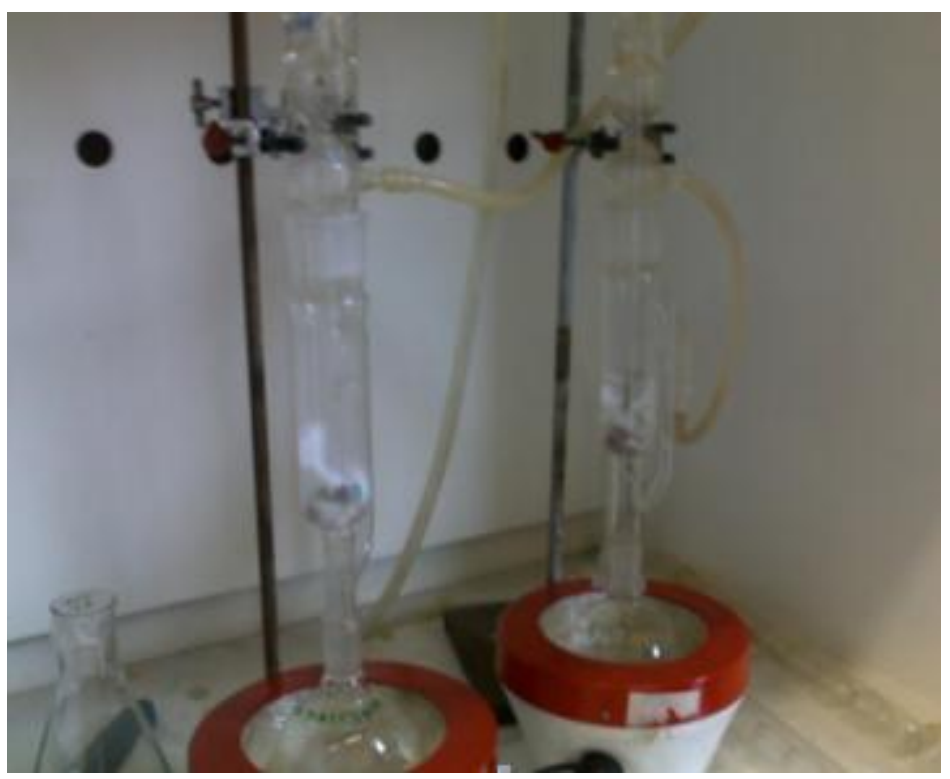

Figura 6. Extrator Sohxlet utilizado na extração de fração sol-gel. 


\section{RESULTADOS E DISCUSSÃO}

\subsection{Análise visual}

No presente trabalho foi feito um estudo da sensibilidade à radiação de dois tipos de farinha de banana verde. Inicialmente foi observada visualmente as discrepâncias de cor dos 2 tipos de amostras. As diferenças de coloração entre os dois tipos de farinhas de bananas estudados são bastante evidentes como pode ser observado na FIG. 7.

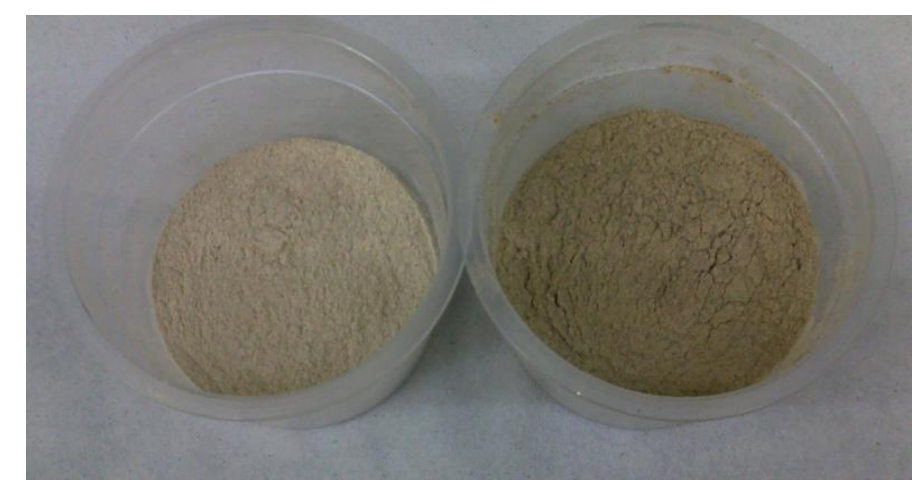

FBV1

FBV 2

Figura 7. Foto comparativa das farinhas de banana verdes estudadas.

As diferenças podem ser atribuídas à falta de padronização do tipo e grau de maturação das bananas utilizadas na obtenção das farinhas. Ramos et al, (2009) concluíram num estudo sobre conteúdo de AR de diversos tipos de banana, que este variava em relação ao genótipo utilizado para a confecção da farinha de banana. Por outro lado, esses autores encontraram que todas as FBV avaliadas apresentavam consideráveis teores de AR, cujos valores variaram de 10 a $40 \%$, dependendo do genótipo.

Também deve ser levado em consideração o porcentual de fibras que pode estar contido nas diversas farinhas, uma vez que alguns tipos de FBV são 
produzidos com casca e outros não. Esse fato já foi mencionado na literatura (TAB. 5).

Tabela 5. Composição centesimal de farinhas de banana verde (FBV) com casca e sem casca, segundo Pereira, 2007.

\begin{tabular}{|c|c|c|c|}
\hline $\begin{array}{l}\text { Componente } \\
(\mathrm{g} / 100 \mathrm{~g})\end{array}$ & & FBV com casca & FBV sem casca \\
\hline Umidade & & $8,7 \pm 0,21$ & $7,1 \pm 0,18$ \\
\hline Proteínas & & $4,33 \pm 0,0084$ & $4,14 \pm 0,078$ \\
\hline Lipídeos & & $0.701 \pm 0,001$ & $0,453 \pm 0,009$ \\
\hline Cinzas & & $2,72 \pm 0,08$ & $1,084 \pm 0,06$ \\
\hline Carboidratos & & $83,94 \pm 0,09$ & $86,92 \pm 0,08$ \\
\hline & Amido total & $69,11 \pm 0,62$ & $75,72 \pm 0,43$ \\
\hline & Amido disponível & $36,44 \pm 0,02$ & $37,485 \pm 0,34$ \\
\hline & Amido resistente & $32,67 \pm 0,88$ & $38,245 \pm 0,09$ \\
\hline Fibra total & & 14,83 & 11,2 \\
\hline
\end{tabular}

Pereira (2007) encontrou maiores valores de proteína, lipídeos, cinzas e fibras nas farinhas obtidas de banana com casca quando comparados com os mesmos constituintes presentes na farinha sem casca, sendo essa diferença significativa para os constituintes: lipídeos, cinzas e fibras. As cascas dos frutos possuem importante conteúdo de minerais, e suas paredes celulares apresentam elevados teores de fibras, justificando a sua maior presença quando comparado com as polpas dos frutos (PEREIRA, 2007).

Farinhas de diferentes origens possuem diferentes conteúdos de umidade que dependem do processo empregado para sua obtenção (TRIBESS et 
al., 2009), o que também influencia na cor apresentada pelo produto. BEZERRA et al. (2010) analisando resultados de calorimetria de varredura diferencial (DSC) das FBV, com casca e sem casca, sob diferentes graus de umidade, concluíram que a adição de água na farinha promoveu um deslocamento nas temperaturas de fusão do sistema, justificada pela energia adicional necessária para o rompimento das ligações da molécula de água. Quando comparado à farinha com casca a $8 \%$ com a farinha sem casca a $7 \%$, observa-se que aquela inicia sua gelatinização a uma temperatura menor.

\subsection{Fração Sol Gel}

A TAB 6 apresenta o resultado da determinação da fração sol-gel. Na amostra irradiada com $3 \mathrm{kGy}$ houve diminuição da fração sol-gel. Isto pode ser indicação de aumento da degradação ou despolimerização do amido, principal componente da FBV.

Tabela 6. Fração sol gel da FBV 1.

\begin{tabular}{ccc}
\hline Dose & Fs $(\%)$ & Fg $(\%)$ \\
\hline 0 kGy & $86,13 \pm 0,97$ & $13,87 \pm 0,97$ \\
3 kGy & $91,52 \pm 0,68$ & $8,48 \pm 0,68$ \\
\hline
\end{tabular}

\subsection{Colorimetria}

Conforme consta nas FIG 8 e 9, houve diferença significativa entre a FBV1 e FBV2 em relação ao teste de colorimetria $L^{*}$, a qual mede a intensidade de cor, que varia de 0 (preto) a 100 (branco). Analisando as figuras, observa-se que o valor de $L^{*}$, aumenta ligeiramente com a dose de radiação (FIG 8). Já a FBV2, tem o mesmo comportamento que a FBV não irradiada, mas a amostra irradiada a 3 kGy apresentou valor de $L^{*}$ reduzido. 


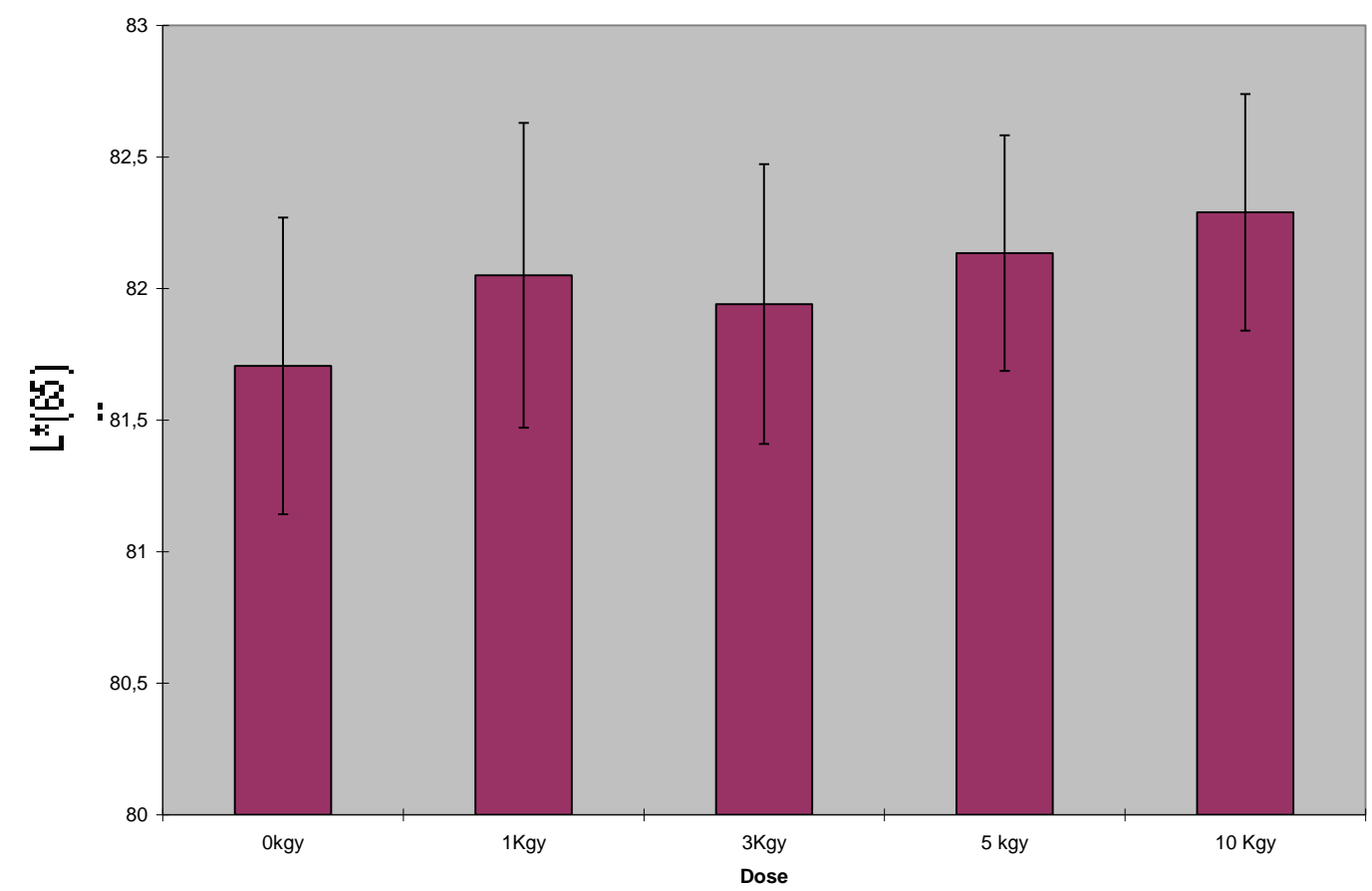

Figura 8. Analise colorimétrica da farinha de banana verde (FBV1) irradiada em diversas doses.

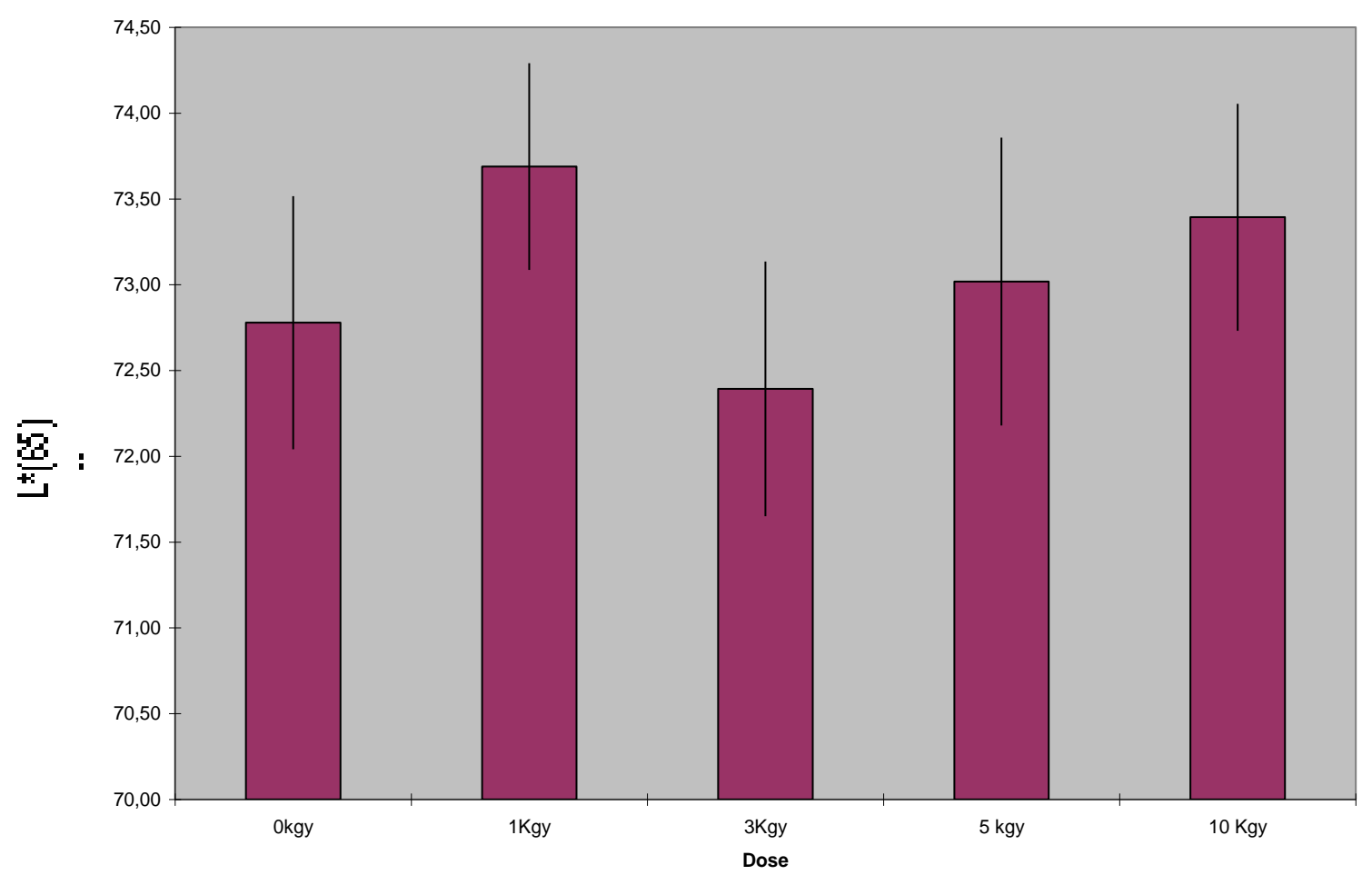

Figura 9. Analise colorimétrica de amostras da FBV2 irradiada em diversas doses. 


\subsection{Determinação do $\mathrm{pH}$}

$\mathrm{O} \mathrm{pH}$ representa a grandeza físico-química potencial hidrogénico ou potencial de hidrogénio iónico, visto ser calculado a partir da concentração de ions hidrogénio $(\mathrm{H}+)$ numa solução. A partir do valor do $\mathrm{pH}$ descobre-se o grau de acidez ou basicidade/alcalinidade dessa mesma solução.

Foram realizadas medidas de $\mathrm{pH}$ nas soluções das diversas amostras de FBV (TAB 7). Os valores encontrados de pH não apresentaram diferenças que possam ser atribuídas à radiação, mesmo para a maior dose empregada.

Tabela 7. Valores médios de pH da FBV 1 e FBV 2 diluiídas a 3\% após aplicação de diferentes doses de radiação gama. Cada medida é a média de três repetições \pm desvio padrão.

\begin{tabular}{ccc}
\hline $\begin{array}{c}\text { Dose } \\
\text { (kGv) }\end{array}$ & FBV 1 & pH \\
0 kGy & $5,7 \pm 0,2$ & FBV 2 \\
1 kGy & $5,68 \pm 0,2$ & $6,25 \pm 0,2$ \\
3 kGy & $5,5 \pm 0,3$ & $6,22 \pm 0,3$ \\
$5 \mathrm{kGy}$ & $5,73 \pm 0,3$ & $6,18 \pm 0,3$ \\
$10 \mathrm{kGy}$ & $5,73 \pm 0,2$ & $6,25 \pm 0,3$ \\
& & $6,15 \pm 0,3$ \\
\hline
\end{tabular}

Os dados de $\mathrm{pH}$ obtidos para FBV1 coincidem com os valores achados por SUNTHARALINGAM \& RAVINDRAN, (1993) que foram pH entre 5.4 e 5.7, mas não com aqueles apresentados pela FBV2.

Pode-se inferir assim, que a composição em carboidratos achada por esses autores (70\% amido, 12\% polissacarídeos não amido e 2,8\% açúcares solúveis) seja semelhante à da FBV1 utilizada no presente trabalho. 


\subsection{Viscosimetria}

O estudo da ação da radiação sobre a farinha de banana verde é fundamentalmente o estudo sobre a ação da radiação sobre os carboidratos contidos nas amostras, uma vez que os carboidratos ou polissacarídeos compõem de $84 \%$ a $87 \%$ dessa farinha (TAB 1). Segundo esse estudo, o amido perfaz de $70 \%$ a $76 \%$ desse conteúdo. Assim sendo, nas medidas de viscosidade estaria sendo medido fundamentalmente o comportamento do amido.

Foram realizados ensaios preliminares para estabelecer as concentrações adequadas para realizar as analises de viscosimetria da farinha de banana verde (FBV). Foram preparadas amostras de $50 \mathrm{ml}$ de FBV não irradiada em diluições de 1, 3, 5 e 10 \% de FBV em água destilada. As amostras foram aquecidas dez minutos com agitação constante. Foi observado que as amostras apresentaram decantação de partículas sólidas em algumas diluições, não se tornando um liquido uniforme. Isso ocorreu nos dois tipos de farinha utilizados. A partir desses ensaios foram consideradas as diluições mais adequadas as de $3 \%$ e $5 \%$.

A temperatura de $70^{\circ} \mathrm{C}$ foi escolhida para as medições de viscosidade, após estabelecer que a temperaturas inferiores as amostras não apresentaram-se homogêneas (FIG 10).

Foram realizados ensaios com amostras de FBV1 irradiadas a 0, 1, 3, 5 e 10 kGy.

Não foi possível realizar medidas de viscosidade com a FBV2, pois após diluição as amostras apresentaram grumos provavelmente pela presença de quantidade significativa de casca de banana verde em sua composição.

Todas as amostras ensaiadas apresentaram-se como fluidos nãonewtonianos, pois sua viscosidade variou com a tensão de cisalhamento, torque e velocidade de rotação. Quando há interação entre os componentes de um fluido e 
essas interações dependem e afetam a velocidade de deformação causada por forças externas, então o fluido é chamado não-Newtoniano.

Viscosidade $x$ Temperatura

farinha de banana verde a $5 \% 3 \mathrm{kGy}$

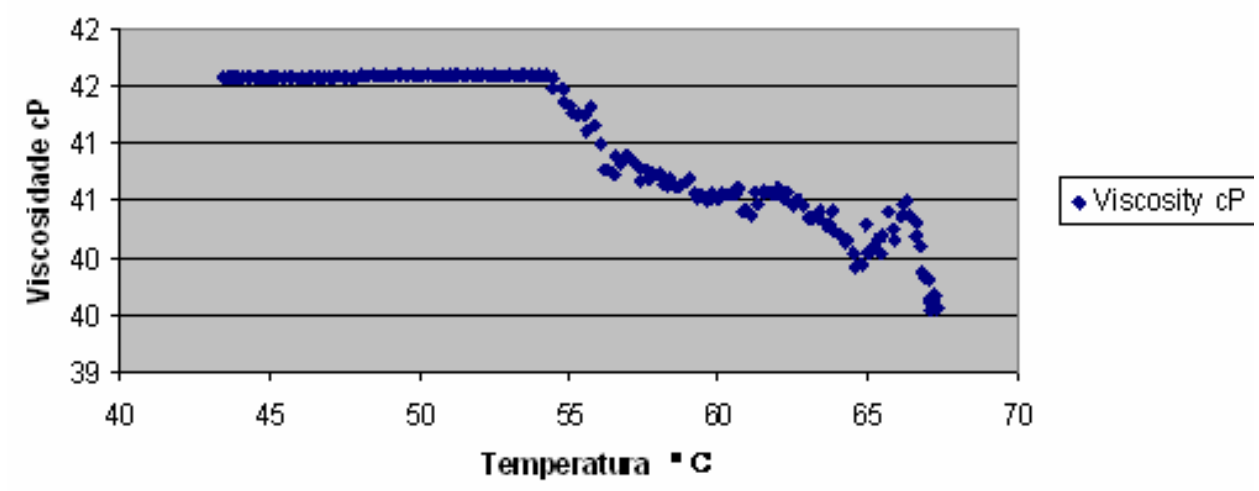

Figura 10. Viscosidade em função da temperatura em ${ }^{\circ} \mathrm{C}$ de amostra de FBV a $5 \%$ irradiada a 3 kGy.

A essa categoria pertence a grande maioria dos colóides hidrofílicos. $\bigcirc$ coeficiente de viscosidade para estes sistemas varia com a tensão aplicada e é chamado de viscosidade aparente.

A FIG. 11 descreve a relação da viscosidade aparente e a tensão de cisalhamento de todas as amostras ensaiadas. A FIG. 12 mostra a distribuição da viscosidade média de hidrogéis de FBV a $5 \%$ com spindle $T-A$. 


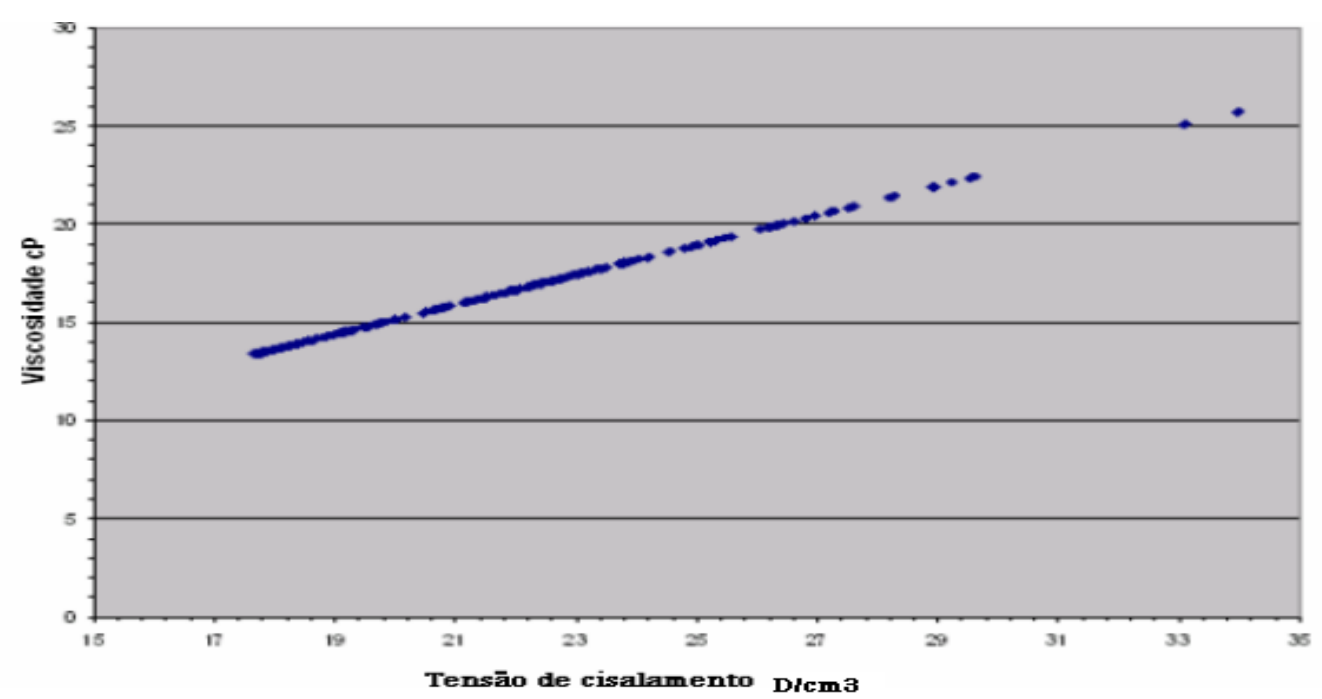

Figura 11 - Relação entre a viscosidade aparente e tensão de cisalhamento de todas as amostras.

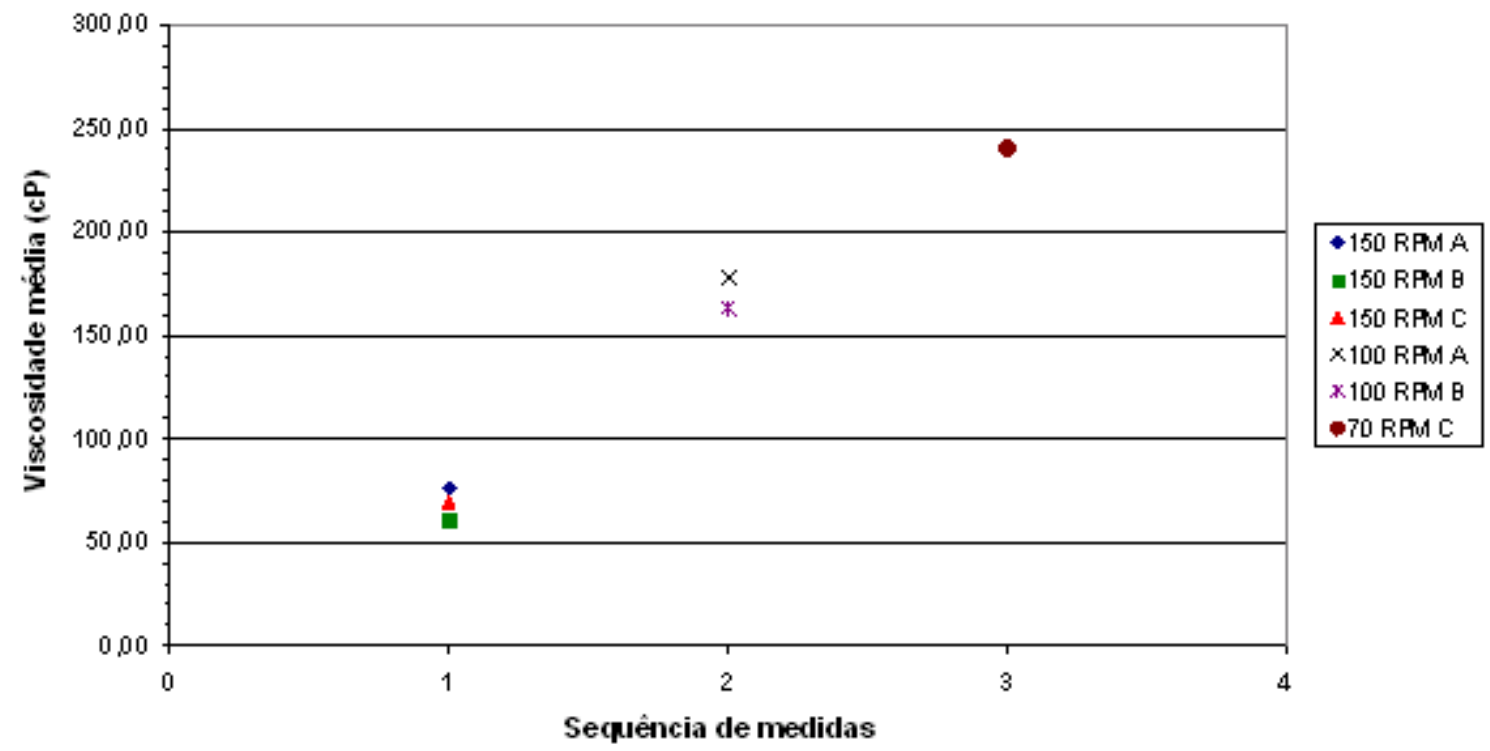

Figura 12 - Distribuição da viscosidade média de hidrogéis de FBV a 5\% com spindle $\mathrm{T}-\mathrm{A}$.

A FIG. 13 descreve a relação da viscosidade e torque de todas as amostras ensaiadas. A FIG. 14 apresenta a relação do torque e a tensão de cisalhamento de todas as amostras. 


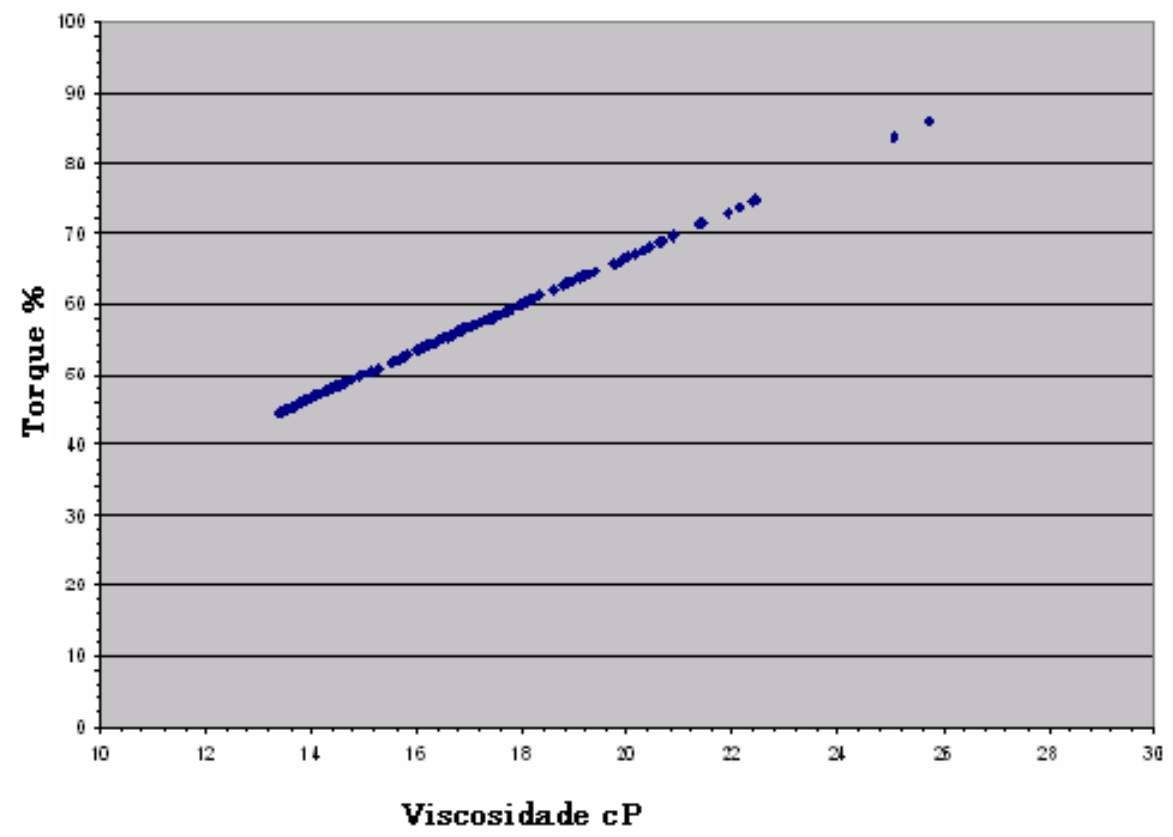

FIGURA 13- Relação entre a viscosidade e Torque de todas as amostras

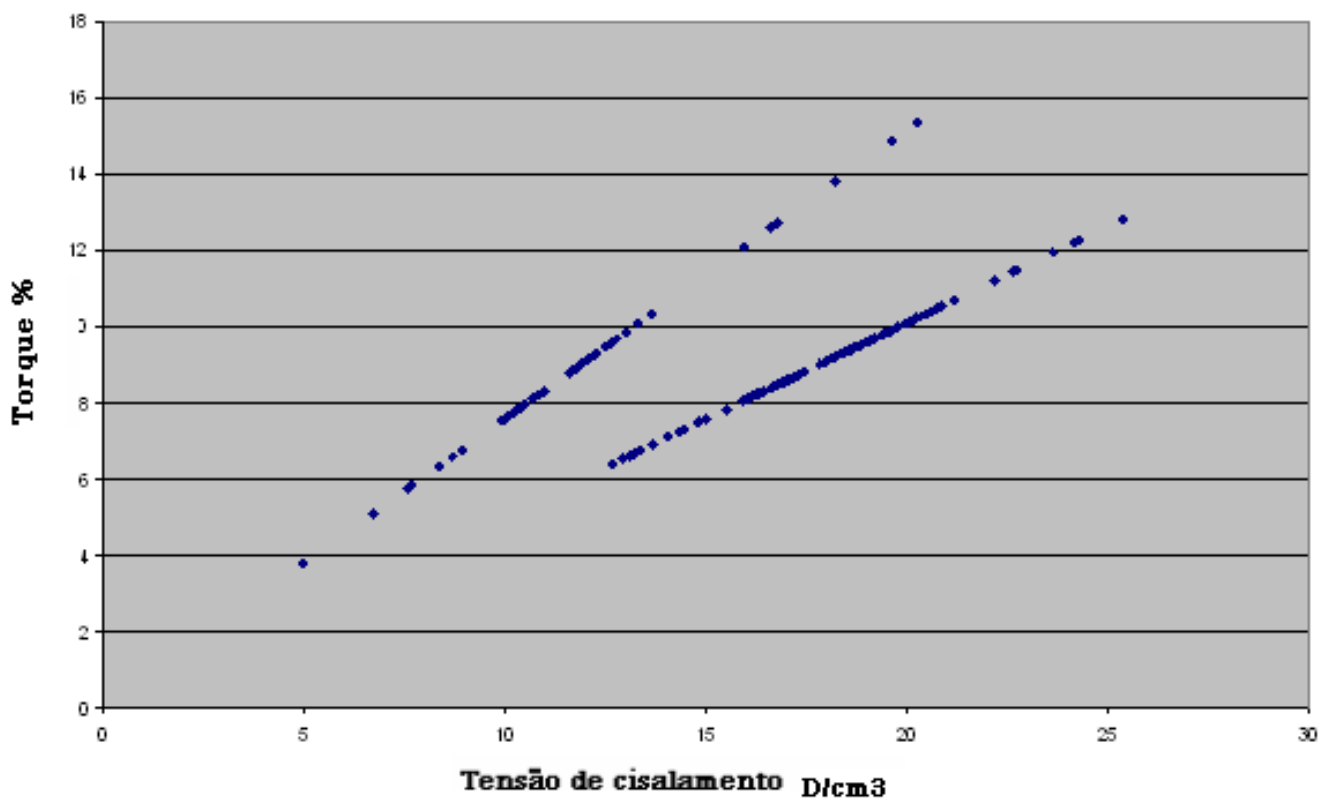

Figura 14- Relação entre torque e tensão de cisalhamento de todas as amostras.

$\mathrm{Na}$ FIG 15. são apresentados os resultados da determinação da viscosidade aparente medida a $70^{\circ} \mathrm{C}$ das amostras, fazendo uma comparação das viscosidades de soluções de FBV a 3\% e 5\% em função das doses de radiação aplicadas, utilizando spindle SC4-18 a 100 RPM. 


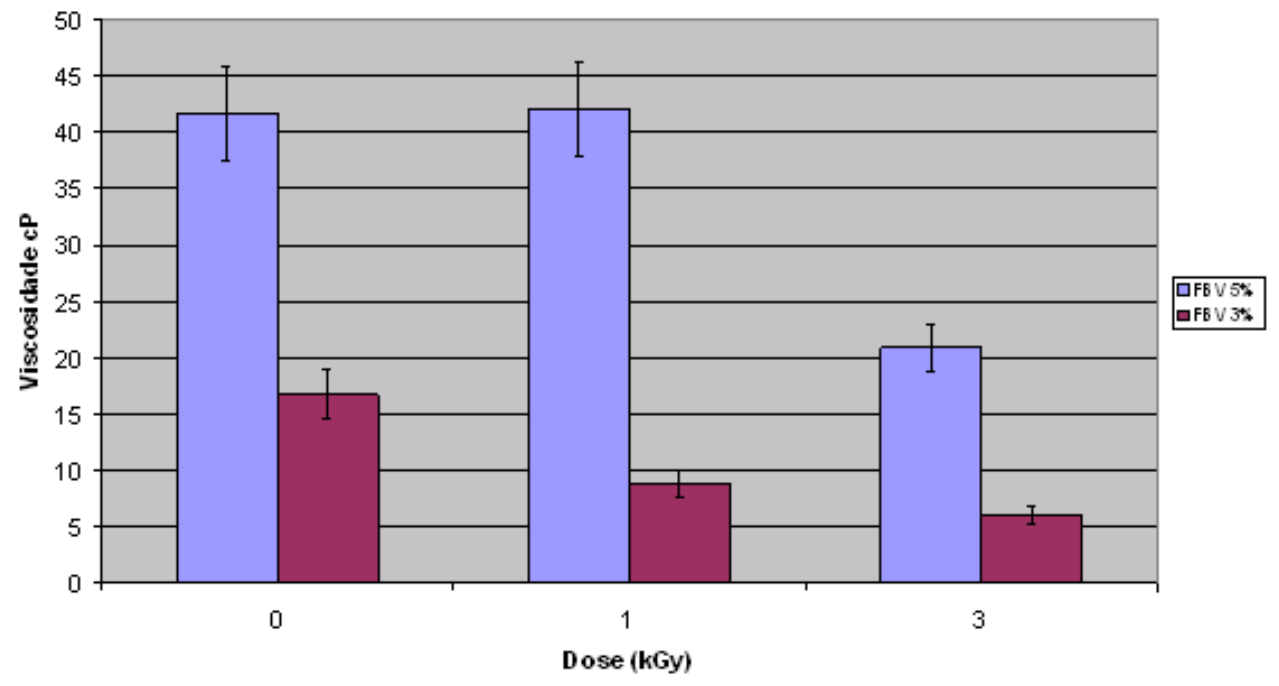

Figura 15 - Viscosidade a $70^{\circ} \mathrm{C}$ em função das doses de radiação de soluções de FBV a $3 \%$ e $5 \%$.

É possível verificar que há influência da ação da radiação sobre a viscosidade destes hidrogéis sendo que a viscosidade aparente decresce com o aumento da dose aplicada.

Chung e Liu publicaram em 2009 trabalho no qual descrevem o efeito da radiação gama em propriedades do amido de milho. Esses autores encontraram um decréscimo no conteúdo aparente de amilose com o aumento da dose de radiação acompanhado pelo aumento de cadeias curtas e uma diminuição de cadeias mais longas. Também, houve um decréscimo na cristalinidade com o aumento da dose de radiação. Em relação ao conteúdo em amido resistente, houve um pequeno decréscimo nas amostras irradiadas com $2 \mathrm{kGy}$ mas verificou-se um aumento com valores maiores até $50 \mathrm{kGy}$.

Não foi possível realizar medidas com diluição de 3\% para as doses de 5 e 10 kGy pois a solução apresentou-se totalmente fluida incompatível de ser medida com os spindles disponíveis. Os dados obtidos sugerem alta 
radiossensibilidade dos componentes da FBV, como observado anteriormente com soluções de outros carboidratos (ALISTE et al., 2000).

O conhecimento da ação da radiação sobre carboidratos ou polissacarídeos deriva de estudos sobre radiólise de soluções aquosas e mudanças radioinduzidas em monossacarídeos e polissacarídeos no estado sólido (IAEA, 1973; YOSHII, 2004). Graças a esses estudos sabe-se que quando analisadas as propriedades físicas de polissacarídeos submetidos à radiação ionizante aparece como mudança fundamental a despolimerização via a cisão da cadeia polimérica. 0 decréscimo apreciável na massa molecular na presença de oxigênio é também atribuído a esse fenômeno. A radiólise de moléculas envolvidas na estrutura hidrocoloidal é que conduziria à formação de macroradicais primários, degradação do polímero e perda de estrutura cristalina (KOROTCHENKO \& SHARPATVI, 2004).

Seja na área da saúde ou em ciência dos alimentos, o interesse sobre a ação da radiação em sistemas polissacarídicos é poder produzir um efeito biológico previsível. Entretanto, o efeito observado é sempre resultado de uma inumerável quantidade de reações complicadas, produzidas por processos de transferência físicos e químicos, recombinações etc.

\subsection{Textura}

As características do alimento podem ser acompanhadas pela análise de textura (VAN NIEUWENHUYZEN et al., 2006). Foram realizadas medidas de textura para os hidrogéis de FBV1 e FBV2. É possível observar (FIG. 16 e 17) que a ruptura do gel à compressão ocorre a diferentes valores de forças e distâncias para os dois tipos de FBV. Nas figuras 18 e 19, observa-se que amostras de FBV2 irradiadas a 3 kGy, apresentaram uma força de ruptura mais alta quando comparado com as outras doses. Al-Assaf, Phillips \& Williams (2006) ponderam que mudanças nas propriedades físicas refletem mudanças moleculares. Assim, pode-se supor que a formação de agregados moleculares seriam os responsáveis por esse aumento. Analogamente, Jo et al. (2005) \& Lee et al. (2005) observaram que a 
porcentagem de elongação de filmes a base de pectina e filmes de glúten também diminuíam com o aumento da dose de radiação.

As FIG 18 e 19 mostram que a FBV irradiada a 1 kGy mantém suas características de textura praticamente inalteradas.

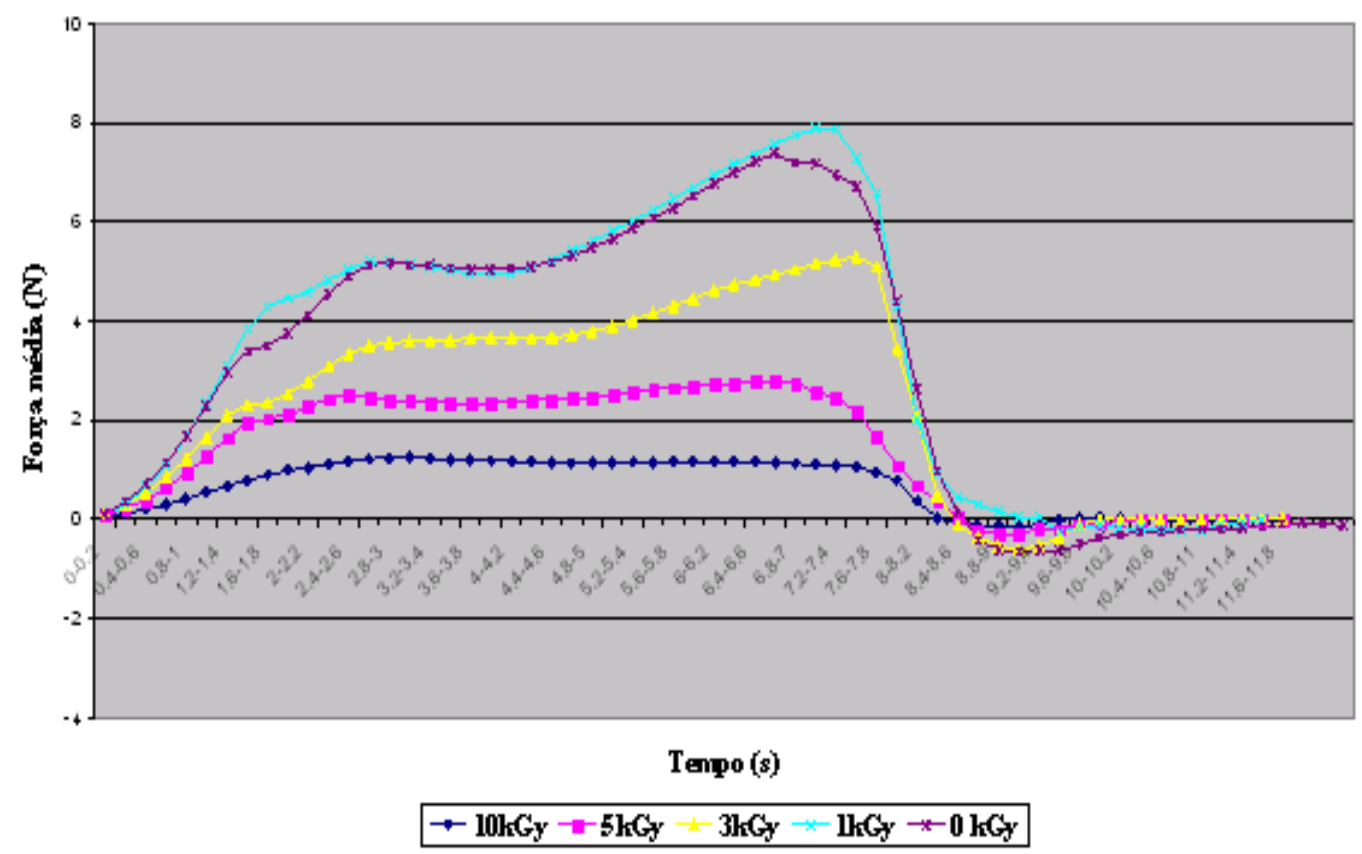

Figura 16 - Perfil de Força-Distância de hidrogel de FBV1 irradiada em diferentes doses. 


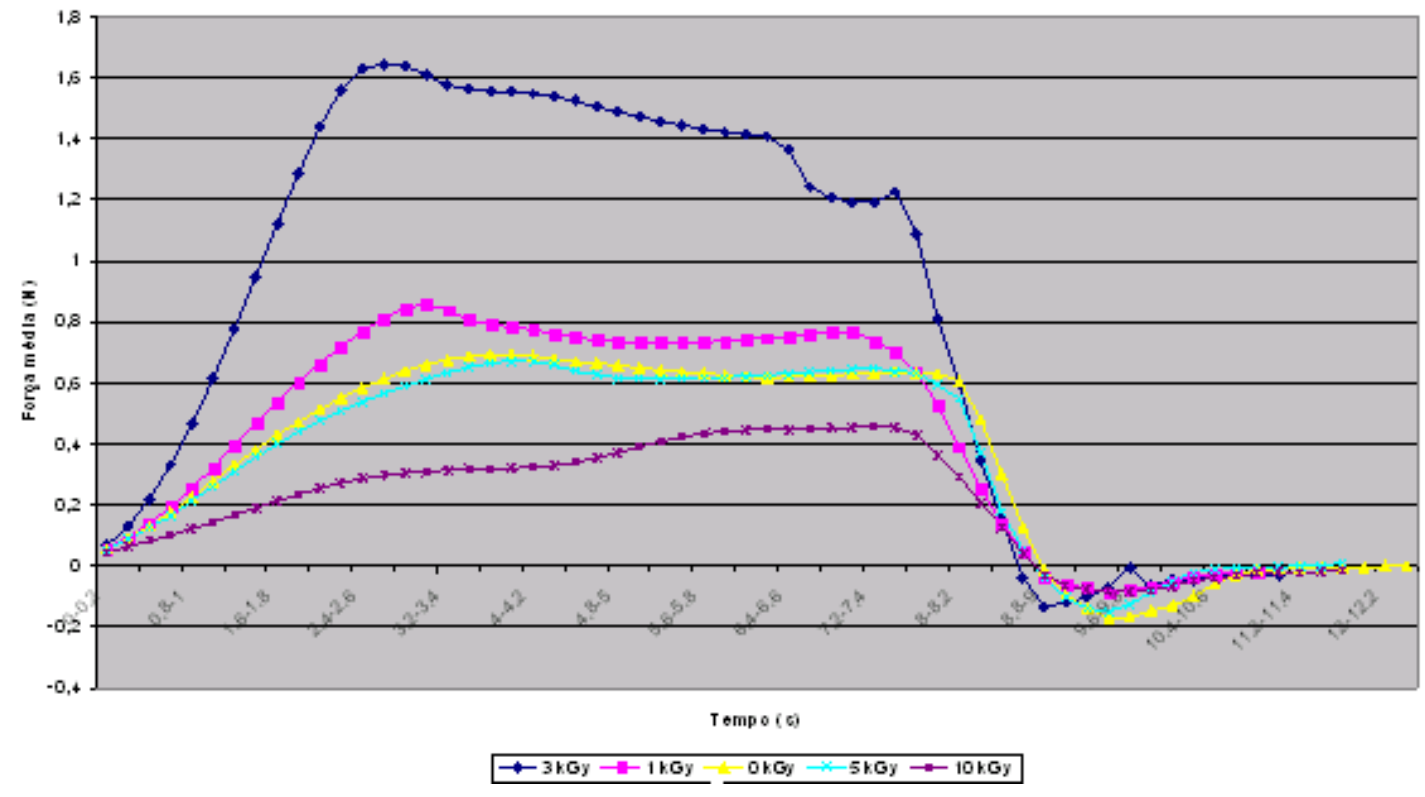

Figura 17 - Perfil de Força-Distância de hidrogel de FBV2 irradiada em diferentes doses.

As FIG. 18 e 19 apresentam os dados de Força máxima de ruptura de hidrogéis de FBV1 e FBV2 respectivamente.

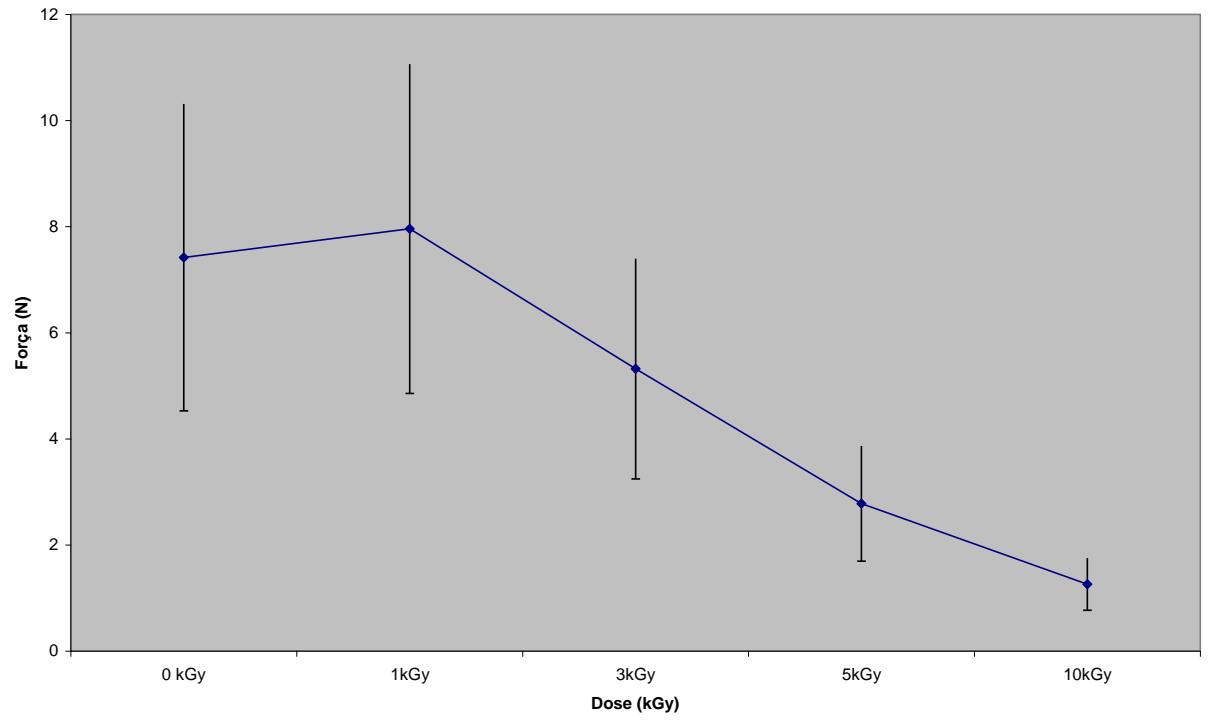

Figura 18 - Força máxima de ruptura de hidrogel de FBV1 irradiada em diferentes doses. 


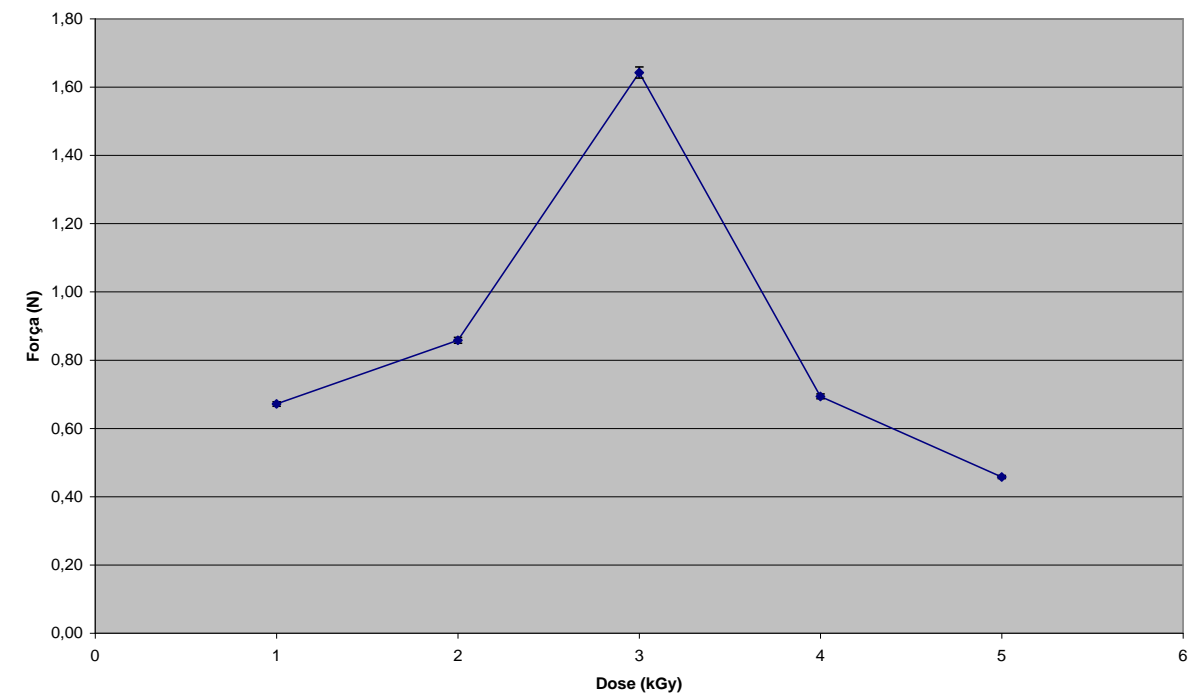

Figura 19. Força máxima de ruptura de hidrogel de FBV2 irradiada em diferentes doses.

Nas FIG 20 e 21 são apresentados perfis comparativos de forçadistância de hidrogel de FBV1 e FBV2 em diferentes doses pela análise de textura. Em todas as doses de radiação aplicada, a FBV1 apresentou maior resistência de ruptura como pode ser observado nessa figura. 
Farinha de Banana Verde 1 e 2 Não Irradiadas

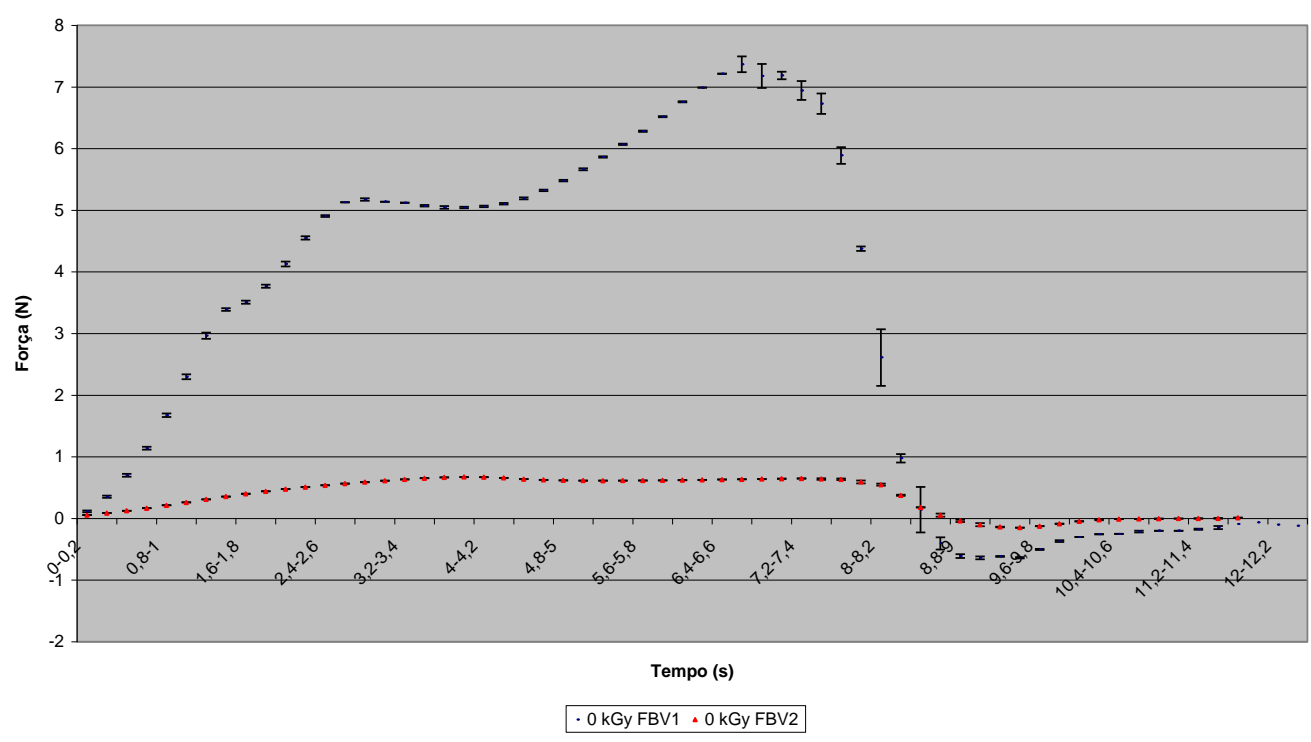

Farinha de Banana Verde 1 e 2 irradiadas a dose de 1 kGy

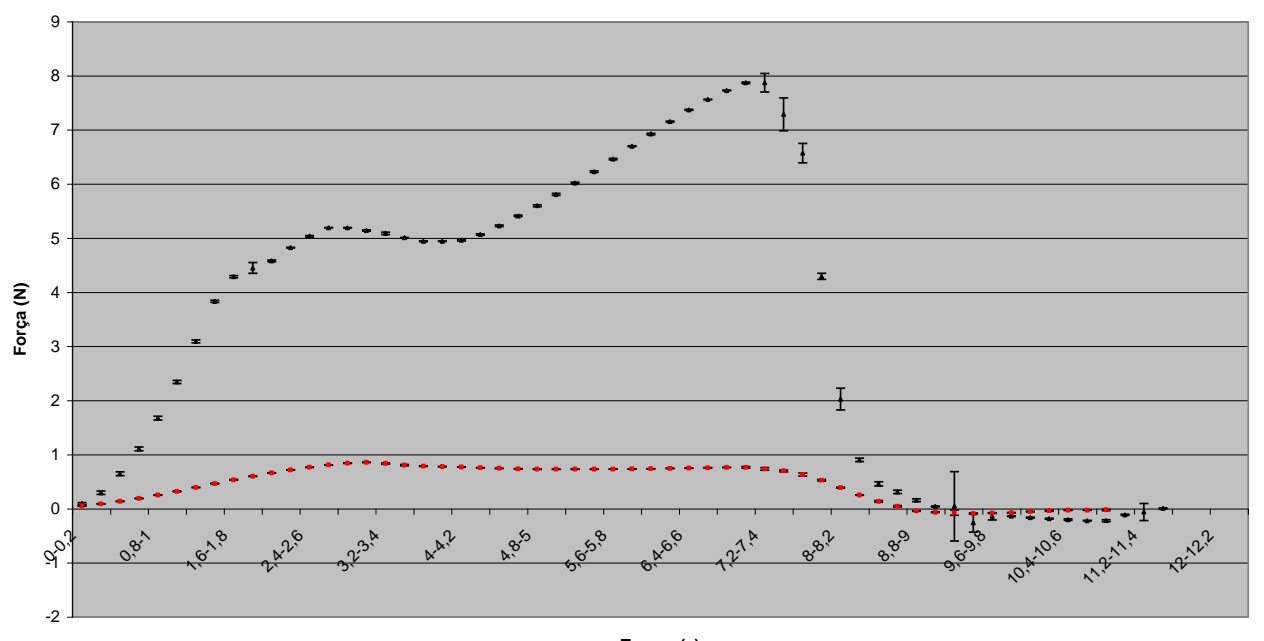

Tempo (s)

$\bullet$ 1kGy FBV1 + 1 kGy FBV2

Figura 20 - Perfil comparativo de força-distância de hidrogel de FBV 1 e 2 em doses 0 e 1 kGy pela análise de textura. 
Farinha de Banana Verde 1 e 2 irradiadas a dose de $3 \mathrm{kGy}$

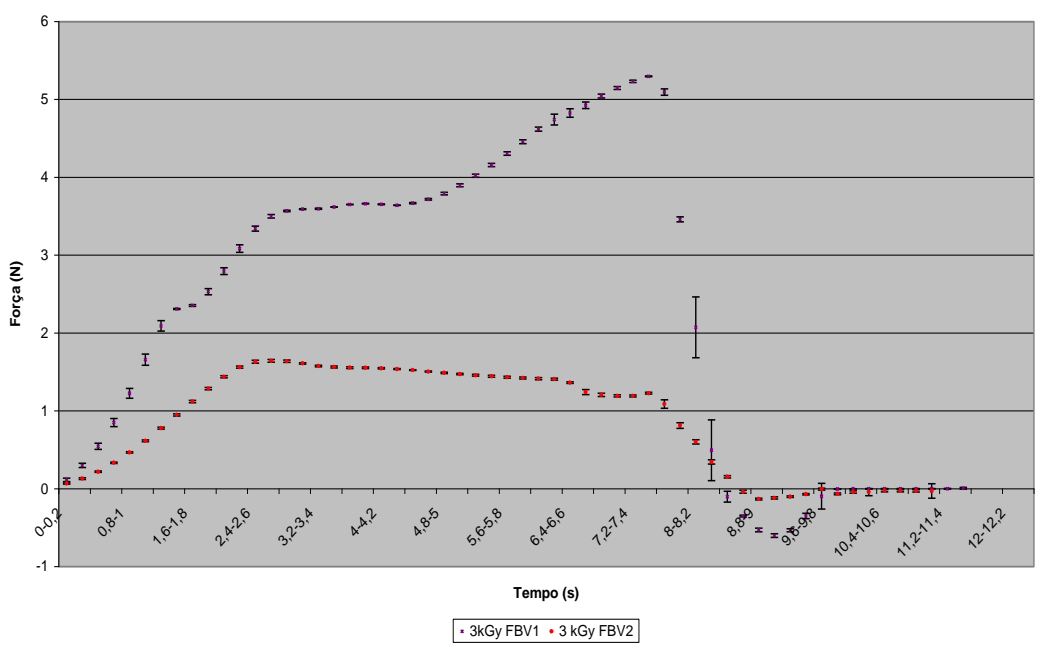

Farinha de Banana Verde 1 e 2 irradiadas a dose de 5 kGy

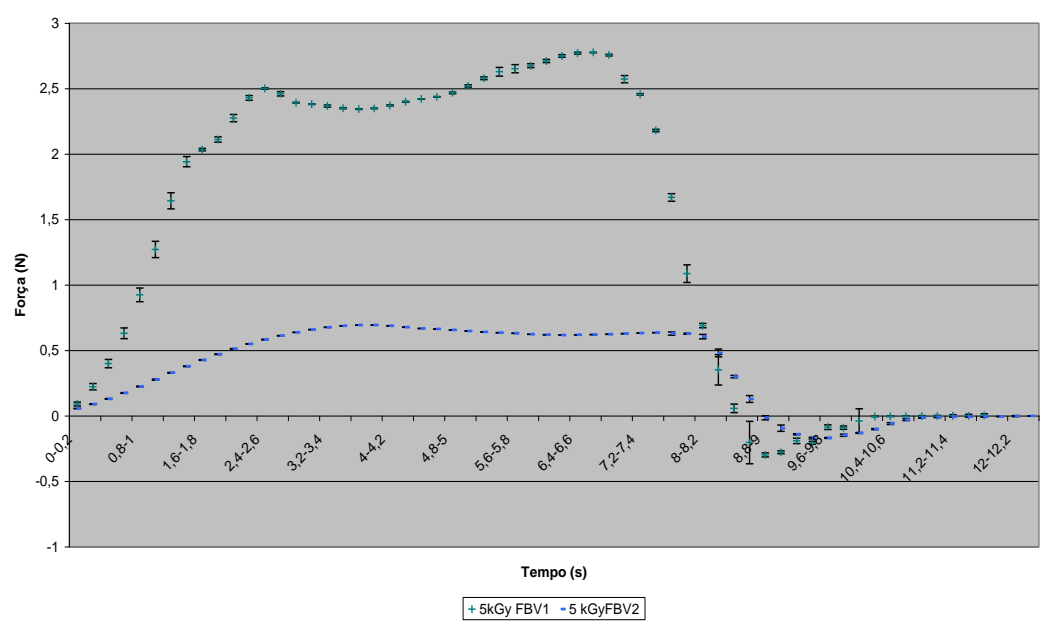

Farinha de Banana Verde 1 e 2 irradiadas a dose de 10 kGy

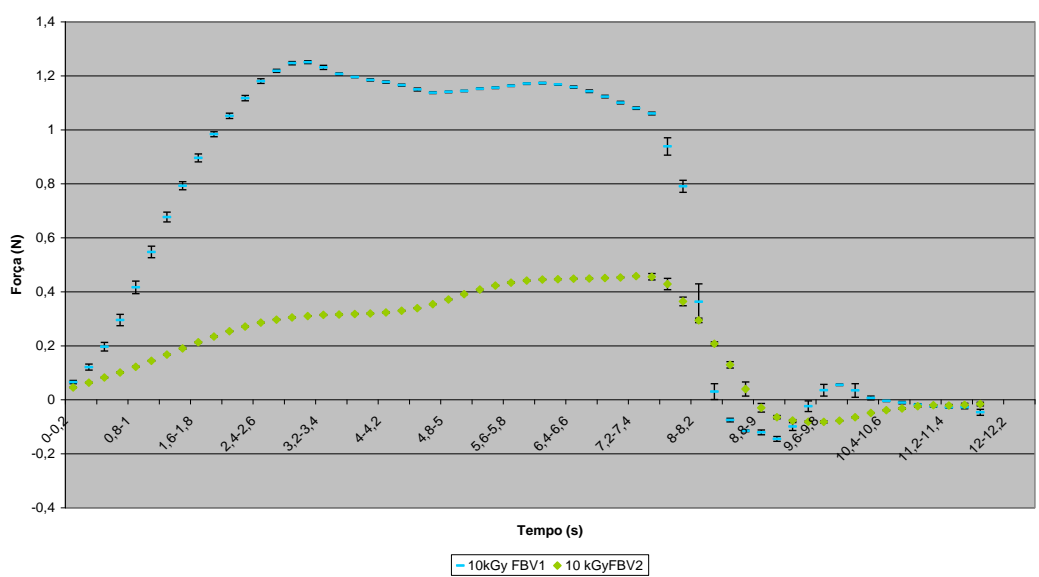

Figura 21. Perfil comparativo de força-distância de hidrogel de FBV 1 e 2 em doses 3,5 e 10 pela análise de textura. 


\section{CONCLUSÃO}

Com base no trabalho realizado conclui-se que:

- As soluções de FBV apresentaram-se como fluidos não-newtonianos, pois a viscosidade se altera com a tensão de cisalhamento e o torque.

- A irradiação não alterou significativamente $\circ \mathrm{pH}$ dos hidrogéis de Farinha de Banana Verde FBV1 e FBV2. Os valores de $\mathrm{pH}$ foram diferentes para os dois tipos de FBV utilizados.

- A viscosidade de maneira geral aumenta com o aumento da concentração das amostras e diminui com a dose de radiação aplicada;

- Para a hidrogeis de FBV em baixa concentração, a irradiação parece exercer maior influência sobre a viscosidade,

- A força de ruptura de hidrogéis de FBV1 decresce conforme se aumenta a dose de irradiação. A FBV2, entretanto, apresentou força de ruptura aumentada a 3 kGy.

- A irradiação de amostras de farinha de banana verde leva à obtenção de produtos com menor viscosidade o que pode ser de interesse da indústria de alimentos. Em aplicações na área da saúde, por exemplo, é importante contar com ingredientes de alto valor nutricional e baixa densidade, como é o caso da introdução de farinha de banana verde em dietas enterais. 


\section{Referências Bibliográficas}

AGUSTIN, M.A.; SANGUANSRI, P.; HTOON, A. Functional performance of a resistant starch ingredient modified using a microfluidiser. Innov. Food Sci. Emer.Tec, v. 9, n. 2, p. 224-231, 2008.

AL-ASSAF, S.; PHILLIPS, G.O.; WILLIAMS, P.A. Controlling the molecular structure of food hydrocolloids. Food Hydroc, v. 20, n. 2-3, p. 369-377, 2006

ALISTE, A.J.; MASTRO, N.L.d. Ascorbic acid as radiation protection on polysaccharides used in food industry. Coll. Surf. Phys. Eng. Asp. v. 249, n. 13, p. 131-133, 2004.

ALISTE, A.J.; VIEIRA, F.F.; MASTRO, N.L. Radiation effects on agar, alginates and carrageenan to be used as food additives. Radiat. Phys. Chem., v. 57, n. 3-6, p. 305-308, 2000.

ANDREWS, L.S.; AHMEDNA, M.; GRODNER, R.M.; LIUZZO, J.A.; MURANO,P.S.; MURANO, E.A.; RAO, R.M.; SHANE, S.; WILSON, P.W. Food preservation using ionizing radiation. Rev. food Env. Cont. Tox., v. 154, p. 1-53, 1998.

ANNISON, G; TOPPING,D.L. Nutritional role of resist starch: chemical struture vs physiological function. Annual Rev. Nutr,, n. 14, p. 297-320,1994.

ARAUJO, E, M. MENEZES, H, C. Formulação com alimentos funcionais para nutrição enteral ou oral. Ciênc. Tecnol. Aliment., v. 26 n. 3, p. 533-538, 2006.

ASP, N.G; van AMELSVOORT, J.M.M; HAUTVAST, J.G.A.J. Nutrictional implications of consuptions of resistant starch in man ( Europian FLAIR Concerted action n.11- COST 911) s.l.p Flair Proceeding of the concluding plenary meeting of EURESTA; 204p 1994.

BASSINELLO, P.Z.; FIORAVANTE, A.P.; NASCIMENTO, J.R.O.; CORDENUNZI, B.R.; LAJOLO, F.M. Distribuição da sacarose-fosfato sintetase em bananas durante o amadurecimento. Cien. Tecnol. Aliment., v. 19, n. 1, p. , 1999.

BERGGREN,A.M;BJORCK,I.M;NYMAN,E.M;EGGUM,B.O. Short- chain fatty acid content and $\mathrm{pH}$ in ceacum of rats fed various sourse of starch. J. Sc. Food Agricultur., v..68, p. 241-248,1995. 
BERRY, C.S. Resistant starch: formation and measurement of starch that survives exhaustive digestion with amylolytic enzymes during the determination of dietary fibre. J. Cereal Sci., v. 4, p. 301-314, 1986.

BEZZERA, C.V.; COSTA, C.M.F.; RODRIGUES, A.M. C.; SILVA, L.H.M. Avaliação da Influencia do Teor de Água na Temperatura de Gelatinização de Farinhas deBanana Verde usando o DSC. Anais do VII Com. Bras. de Anal. Térm. e Calor.- São Pedro, SP, Brasil, 25 a 28 de Abril de 2010.

BOTHAM, R.L. et al. A physicochemical characterization of chick pea starch resistant to digestion in the human small intestine. Carbohyd. Polym., v. 26, p. 83-90, 1995.

BRASIL. ANVISA. Resolução RDC no 12, de 02 de Janeiro de 2001. Aprova o regulamento técnico sobre padrões microbiológicos para alimentos. Publicada no DOU de 10 de janeiro de 2001

BRASIL. ANVISA. Resolução RDC no 21, de 26 de janeiro de 2001. Aprova regulamento técnico para irradiação de alimentos. Publicada no DOU de 29 de janeiro de 2001.

BRASIL. Ministério da Saúde. Decreto no 72. 718, de 29 de agosto de 1973. Estabelece normas gerais sobre irradiação de alimentos. Publicada no Diário Oficial da União de 30 de agosto de 1973.

BRASIL. Ministério da Saúde. Decreto-Lei no 986, de 21 de outubro de 1969. Institui Normas Básicas sobre Alimentos. Publicada no DOU de 21 de outubro de 1969. Alterado pela Medida Provisória no 2.190-34, de 23 de agosto de 2001.

BUARQUE de HOLANDA FERREIRA, A. Novo Dicionário da Língua Portuguesa, 1a. Edição, Ed. Nova Fronteira, p. 180, 1975.

CAC (CODEX ALIMENTARIUS COMMISSION). Codex General Standard for Irradiated foods. Codex Stand. 106-1983. Rev. 1 - 2003.

CAMGRONDON, I.G.; MARTIN-CARRON, N. Fermentación colónica de fibra dietetica y almidón resistente. In: LAJOLO, F.M.; SAURA-CALIXTO, F.; PENNA, E.W.; MENEZES, E.W. . (eds.) Fibra dietética em Iberoamerica: tecnologia $y$ salud. Obtención, caracterizacion, efecto fisiológico $y$ aplicacion em alimentos. Proyecto CYTED XI.6. " Obtención y caracterización de fibra dietética para aplicación em regimes especiales"/ CNPq. São Paulo: Varela, p. 331-338. 2001. 
CARVALHO, V.D.; CARDOSO, D.A.M. Industrialização da banana. Inform. Agropec., v. 63, p. 54-60, 1980.

CHAMP, M.; FAISANT, N. Resistant starch: analytical and physiological aspects. Bol. SBCTA, v. 30, n.1, p. 37- 43, 1996.

CHO, S.S,; DREHER, M.L, eds. Handbook of Diet. Fiber. New York, NY: Marcel Dekker, Inc; 2001.

CHUNG, H. -J., LIU, Q. Effect of Gamma Irradiation on Molecular Structure and Physicochemical Properties of Corn Starch. J. Food Sc., v. 74, n. 5, p. C353C361, 2009.

CLENDENNEN, S.K.; MAY, G.D. Differential gene expression in ripening banana fruit. Plant Physiology, v. 115, n. 2, p. 463-469, 1997.

COLONNA P, LELOUP V, BULÉON A. Limiting factors of starch hydrolysis. Eur $\boldsymbol{J}$ Clin Nutr., 46, n. 2, p. S17-S32. 1992.

COPELAND, L.; BLAZEK, J.; SALMAN, H.; TANG, M.C. Form and functionality of starch. Food Hidrocol., v. 23, n. 6, p. 1527-1534, 2009.

COSTA, M.; ANTONIO, M.A.; BRITO, A.R.M.S. Effects of prolonged administration of Musa paradisiaca $L$ (banana), an antiulcerogenic substance, in rats. Phytotherapy Res., v. 11, n. 1, p. 28-31, 1997.

CUMMINGS, J. H.; MACFARLANE, G. T. A review: The Control and Consequences of Bacterial Fermentation in the Human Colon. J. Appl. Bacteriol., n. 70, p. 443-459, 1991.

DA MOTA, R.V.; LAJOLO, F.M.; CIACCO, C.; CONDENUNZI, B.R. Composition and functional properties of banana flour from different varieties. Starch-Starke, v. 52, n. 2-3, p. 63-68, 2000.

DECKER, N.R., ZIEGLER, G. R. The structure of aerated confectionery. Manufac. Confec., v. 82, n. 9, p. 101-108, 2002.

DELINCÉE, H. Detection of food treated with ionizing radiation. Trends Food Sci. Technol., v. 9, n.2, p. 73 - 82, 1998.

DIEHL, J.F. Food Irradiation: is it an alternative to chemical preservatives? Food Addit. Contam., v. 9, p. 409-416, 1992.

DIEHL, J.F. Safety of Irradiated Foods. New York: Marcel Dekker Inc., 1995. 
DREHER ML. Food industry perspective: functional properties and food uses of dietary fiber. In: KRITCHEVSKY, D, BONFIELD, C, editores. Dietary fiber in health \& disease. Minnesota: Eagan Press; p. 467-74, 1995.

DUTCOSKY,S.D. Análise sensorial de alimentos. Curitiba, Champagnat, 123p. 1996.

DZIEZAK, J.D. Instruments for measuring viscosity and flow. Food Tech., v. 45, n. 7, 1991.

EERLINGEN, R.C.; DECEUNINCK, M.; DELCOUR, J.A. Enzyme-resistant starch II. Influence of amylose chain length on resistant starch formation. Cereal Chem., St. Paul, v. 70, n. 3, p. 345-50, 1993.

EGGUM, B.O. et al. The resistant starch, undigestible energy and undigestible protein contents of raw and cooked milled rice. J. Cereal Sc., v. 18, p. 159-170, 1993.

EMBRAPA (EMPRESA BRASILERIA DE PESQUISA AGROPECUÁRIA), Recursos Genéticos e Biotecnologia - Cenargenda Online - Ano I № 31 Semana de 8 a 14 de agosto de 2005.

EMBRAPA. A cultura da banana. Brasília, DF: Editora Embrapa-SPI, p. 9-10, 1997.

ENGLYST, H.N. et al. Determination of the non-starch polysaccharides in plant foods by gas-liquid chromatography of constituent sugars as alditol acetates. Analyst, v. 107, p. 307-318, 1982.

ENGLYST, H.N. et al Measurement of resistant starch in vitro and in vivo . Brit. J. Nutr., v. 75, n. 5, p. 749-775,1996.

ENGLYST, H.N. et al. Classification and measurement of nutritionally important starch fractions. Eur. J. Clin. Nut.r, v. 46, p. S33-S50, 1992.

ENGLYST, H.N. et al. Determination of the non-starch polysaccharides in plant foods by gas-liquid chromatography of constituent sugars as alditol acetates. Analyst, v.107, p.307-318, 1982. CHAMP, M.; FAISANT, N. Resistant starch: analytical and physiological aspects. Bol SBCTA, v. 30, n. 1, p. 37-43, 1996.

ENGLYST, H.N. et al. Polysaccharide breakdown by mixed populations of human faecal bacteria. FEMS Microbiol. Ecol., v. 95, p.163-171, 1987. 
ESCARPA A, GONZALEZ MC, MAÑAS E, GARCIA-DIAZ L, SAURA-CALIXTO F. Resistant starch formation: A standardization of a high-pressure autoclave process. J. Agric. Food Chem., v. 44, p. 924-28, 1996.

FAISANT, N. et al. Digestion of raw banana starch in the smal intestine of healthy humans: structural features of resistant starch. Br. J. Nutr, v. 73, n. 1, p. 111-123, 1995.

FAISANT, N. et al. Structural discrepancies in resistant starch obtained in vivo in humans and in vitro. Carbohyd. Polym., v. 21, p. 205-209, 1993.

FAO (FOOD AND AGRICULTURAL ORGANIZATION): Crops \& Livestock primary \& processed. Disponível em: <http://faostat.fao.org/faostat/collections>. Acesso em: dezembro de 2002.

FASOLIN L , H; ALMEIDA, G.C; CASTANHO, P.S; OLIVEIRA, E.R,N. Biscoitos produzidos com farinha de banana: avaliações química, física e sensorial. Ciênc. Tecnol. Aliment., v .27 n. 3, 2007.

FIORAVANÇO, J. C. Mercado mundial da banana: produção, comércio e participação brasileira. Inform. Econômicas, v. 33, n. 10, p. 15-27, 2003.

FAO (FOOD AND AGRICULTURE ORGANIZATION OF THE UNITED NATIONS, WORLD HEALTH ORGANIZATION). Evaluation of health and nutritional properties of probiotics in food including powder milk with live lactic acid bacteria. Córdoba, 34p. Disponível em: <ftp://ftp.fao.org/es/esn/food/probioreport_en.pdf> 2001.

FOSTER, M.; RODRUIGUEZ,; MARTIN, J.D. ROMERO, C.D. Distribution of nutrients in edible banana pulp. Food Tech. Biotech., v. 41, n. 2, p. 167-171, 2003.

FOSTER, M.; RODRUIGUEZ,; MARTIN, J.D. ROMERO, C.D. Statistical differentiation of bananas according to their mineral composition. J. Agric. Food Chem., v. 50, n. 21, p. 6130-5, 2002.

FREITAS, M.C.J.; TAVARES, D. Q. Caracterização do grânulo de amido de bananas (Musa AAA-Nanicão e Musa AAB-Terra) Ciênc. Tecnol. Aliment., v. 25 , n. 2, p. 217-222, 2005.

FREITAS, M.C.J.; TAVARES, D.Q. Caracterização dos grânulos de amido de bananas (Musa AAA-Nanicão e Musa AAB-Terra). XIV Congresso Brasileiro de Ciência e Tecnologia de Alimentos. Anais do ...Rio de Janeiro, v.1, p. 569-72, 1998. 
FULLER, R. Probiotics in man and animals. J. Appl. Bacteriol., Oxford, v. 66, p. 365-378, 1989.

GALLANT DJ, BOUCHET B, BULÉON A, PÉREZ S. Physical characteristics of granules and susceptibility to enzymatic degradation. Eur. J. Clin. Nutr; v. 46, n. 2, p. S3-S16, 1992.

GIBSON, G.R.; ROBERFROID, M.B. Dietary modulation of the human colonic microbiota: introducing the concept of prebiotics. J. Nutr., Bethesda, v. 125, p.1401-1412, 1995.

GILLILAND, S.E. Probiotics and prebiotics. In: MARTH, E.H., STEELE, J.L., eds. Applied Dairy Microbiology. New York: Marcel Dekker, p. 327-343. 2001.

GOÑI, I. et al. Analysis of resistant starch: a method for foods and food products. Food Chem, v. 56, p. 445-449, 1996.

GUINARD, J.X.; MAZZUCCHELLI, R. The sensory perception of texture and mouthfeel. Trends in Food Science and Technology. v. 7, p. 213-219, 1996.

HARALAMPU, S.G. Resistant starch - a review of the physical properties and biological impact of RS3. Carbohyd. Polym., v. 41, p. 285-292, 2000.

HAYES, D.J.; MURANO, E.A.; MURANO, P.S.; OLSON, D.G.; SAPP, S.G. Food irradiation: a Sourcebook. Ames, I.A.: Academic Press, Inc., 1995.

HOMMA, N. AKAISHI, R.; YOSHII, Y. et al. Measurement of resistant starch content in polished rice and processed rice products. J. Japanese Soc.Food Sc.Technol.-Nippon Shokuhin Kagaku Kogaku Kaishi, v. 55, n. 1, p. 18-24, 2008.

IAEA. Manual on Radiation Sterilization of Medical and Biological Materials, IAEA, Vienna, 1973, Technical Report Series No. 149, Vienna, 1973.

IAEA. Radiation in Everyday Life. Vienna, Austria. 2003. Disponível em: <http://www.iaea.org/icgfi/> Acesso em: 14 ago. 2004.

ICGFI. International Consultative Group on Food Irradiation. Facts about food irradiation., IAEA, Vienna, 1999.

JENKINS, D.J. A, VUKSAN V, KENDALL C.W.C, WURCH, P, JEFFCOATt R, WARING, S, MEHLING, C.C, VIGDEN, E, AUGUSTIN, L.S.A, WONG, E. Physiological effects of resistant starches on fecal bulk, short chain fatty acids, blood lipids and glycemic index. Jour. Amer. Coll. Nutr, v. 17, n. 6, p. 609-16; 1998. 
JENKINS, D.J. et al. Starchy foods and glycemic index. Diabetes Care, v. 11, n. 2, p.149-159, 1988.

JO, C.; KANG, H.; LEE, N.Y.;KWON, J.H.; BYUN, M.W. Pectin- and gelatin-based film: effect of gamma irradiation on the mechanical properties and biodegradation. Radiat. Phys. Chem., v. 72, p. 745-750, 2005.

KABIR, M. ET AL. Dietary amylose-amylopectin starch content affects glucose and lipid metabolism in adipocytes of normal and diabetic rats. J. Nutr., v. 128, n. 1, p. 35-43, 1998.

KAUR, N.; GUPTA, A.K. Applications of inulin and oligofructose in health and nutrition. J. Biosc., Bangalore, v. 27, p. 703-714, 2002.

KAREL, M. Fundamentals of dehydration processes. In: SPICER, A. (Ed.). Advances in pre-concentration and dehydration of foods. London: Applied Sc. Publishers, p. 44-94, 1974.

KILCAST, D. Effect of irradiation on vitamins. Food Chem., v. 49, p. 157-164, 1994.

KILCAST, D. Irradiation and combination treatments. Food Cont. , v.2, n.1, p.6-8, 1991. KOROTCHENKO, K.A.; SHARPATYI, V.A.. Radiation Chemistry of Polysaccharides: 3 . On the strange dose dependence of the buildup of some radiolysis products. High Energy Chem., v. 38, n. 4, p. 231-235, 2004

LAGUNA, L.; SALVADOR, A.; SANZ, T.; FISZMAN, S.M. Performance of a Resistant Starch Rich Ingredient in the Baking and Eating Quality of Short-Dough Biscuits. LWT - Food Sc. Technol., 2010. Published online ahead of print, doi: 10.1016/j.Iwt.2010.05.034 
LAJOLO, F.M. et al. Dietary fiber and resistant starch intake in Brazil recommendation and actual consumption pattern. Food Sc. Technol., v. 113, p. 845-858, 2001.

LANNES, S.C.S. Estudo das propriedades físico-químicas e de textura de chocolates.. Tese de Doutorado- Faculdade de Ciências FarmacêuticasUniversidade de São Paulo. 175p, São Paulo, 1997.

LOBO, A.R; SILVA, G.M.L.S. Amido resistente e suas propriedades físicoquímicas Rev. Nutr., v. 16 n. 2, 2003.

LOHANI, S.; TRIVEDI, P.K.; NATH, P. Changes in activities of cell wall hydrolases during ethylene-induced ripening in banana: effect of 1-MCP, ABA and IAA. Postharvest Biol. Tech., v. 31, n. 2, p. 119-126, 2004.

MACDONALD, L.; SCHASCHKE, C.J. Combined effect of high pressure, temperature and holding time on polyphenoloxidase and peroxidase activity in banana (Musa acuminata). J. Sc. Food Agriculture, v. 80, n. 6, p. 719-724, 2000.

MACDONALD, I.A.; SINGH, G; MAONY, D.E.; MEIER, C.E. Efect of pH on bile salt by mixed fecal cultures. Steroids, v. 32, p. 245-256, 1979.

MASTRO, N.L.d Development of Food Irradiation in Brazil. Progress in Nuclear Energy, v. 35, n.3-4, p. 229-248, 1999a.

MASTRO, N.L.d.. Sterile foods to be used in hospitals and military rations. $\mathbf{B r}$. Res. Devel. J., v. 2, n. 1, p.1-4, 1999b.

MASTRO, N.L.d.; TAIPIRA, M.S; COHEM ,V.H; RODAS, M.A.B; GABERLOTTI, M.L. Avaliação Critica da Polpa de Banana (Musa Spp.) Ver. Hig. Aliment., v. 21, n 153 , p. 39-45, 2007.

MATTILA-SANDHOLM, T.; MYLLÄRINEN, P.; CRITTENDEN, R.; MOGENSEN, G., FONDÉN, R.; SAARELA, M. Technological challenges for future probiotic foods. Int. Dairy J., Amsterdam, v.12, p.173-182, 2002.

MATTHIESEN, M. L.;BOTEON, M. Análise dos principais pólos produtores de banana. Disponível em <http://www.cepea.esalq.up.br/pdf/banana.pdf.>Acesso em mar.2005 
MAYR, D.; MARK, T.; LINDINGER, W.; BREVARD, H.; YERETZIAN, C. Breathby-breath analysis of banana aroma by proton transfer reaction mass spectrometry. Inter. J. Mass Spectrometry, v. 223, n. 1-3, p. 743-756, 2003.

MEDEIROS, M.L.; LANNES, S.C.S. Avaliação da textura de bombons com recheio de longa duração. Rev. Br. Ciên. Farmacêuticas, v. 36, supl.1, p. 48, 2000.

MEDINA, J. C. Banana: cultura, matéria-prima, processamento e aspectos econômicos. 2ํㅡ. ed. Campinas: ITAL, 1995.

MELLOR, C. Natural remedies for common ailments. Panther Books, Granada P. Ltd, Glascow, p. 242, 1984.

MENEZES, E.W.; LAJOLO, F.M. (eds). Contenido en fibra dietética y almidón resistente en alimentos y productos iberoamericanos. Proyecto CYTED XI.6 "Obtención y caracterización de fibra dietética para su aplicación en regímenes especiales". CYTED/CNPq. Docuprint, São Paulo, 121p. 2000

MENEZES, E.W.; GIUNTINI, E.B.; LAJOLO, F.M. Perfil de ingestão de fibra alimentar e amido resistente pela população brasileira nas últimas três décadas. In: LAJOLO, F.M.; SAURA-CALIXTO, F.; PENNA, E.W.; MENEZES, E.W. (eds). Fibra dietética en Iberoamérica: tecnología y salud. Obtención, caracterización, efecto fisiológico y aplicación en alimentos. Proyecto CYTED XI.6 "Obtención y caracterización de fibra dietética para su aplicación en regímenes especiales"/ CNPq. São Paulo: Ed. Varela, p.433-444. 2001.

MUIR, J.G.; O'DEA, K. Measurement of resistant starch: factors affecting the amount of starch escaping digestion in vitro. Am. J. Clin. Nut., v. 56, p. 123-127, 1992.

MUYONGA, J.H.; RAMTEKE, R.S.; EIPESON, W.E. Prehydration steaming changes physicochemical properties of unripe banana flour. J. Food Proces. Preserv., v. 25, n. 1, p. 35-47, 2001.

NAGENGAST, F.M, et al.Inibicion of secindary bile acid formation in the large intestine by lactulose en healthy subjects of two diferent age groups. Eur. J. Clin. Invest., v. 18, p. 56-61,1988. 
NARVAIZ, P. \& LADOMERY, L.G. Estimation of the Effect of Food Irradiation on Total Dietary Vitamin Availability as Compared with Dietary Allowances: Study for Argentina. J. Sci. Food Agrc., .v. 76, p. 250-256, 1998.

NATTRESS, L.A.; ZIEGLER, G.R.; HOLLENDER, R.; PETERSON, D.G. Influence of hazelnut paste on the sensory properties and shelf-life of dark chocolate. J.of Sensory Studies, v. 19, n. 2, p. 133-148, 2004.

NAVARRO, R.F. Fundamentos de reologia de polímeros. Caxias do Sul: EDUCS: Editora da Universidade de Caxias do Sul, 1997

NOUAILHETAS, Y.; ALMEIDA, C.E.B.; PESTANA, S. Radiações lonizantes e a Vida. CNEN, Rio de Janeiro: 42p. Disponível em: http://www.cnen.gov.br/ensino/apostilas/rad_ion.pdf., Acessado em: 11 novembro 2010.

O'DEA, K. et al. Rate of starch hydrolysis in vitro as a predictor of metabolic responses to complex carbohydrate in vivo. Am. J. Clin. Nutr., v. 34, p.19911993, 1981.

OLSON, J. A. Antioxidants in health and disease. In: Natural Protectants against Natural Toxicants (Bidlack, W. R. \& Omaye, S. T., eds.), Tech. Publi., Lancaster, PA. p. 23-34 .1995.

OKEZIE, U.; AKANBI, C.T.; OTUNOLA, E.T.; ADEYEMI, I.A. Effect of addition of ripe bananas on some physico-chemical properties of maize "extract". Inter. Food Sc. Nutr., v. 54, n. 6, p. 437-445, 2003.

OMS. ORGANIZACIÓN MUNDIAL DE LA SALUD. Inocuidad e idoneidad nutricional de los alimentos irradiados. Genebra, 172p. 1995.

OMS. Wholesomeness of Irradiated Food: (TRS 659). World Health Organization, Geneva, Switzerland, 1981.

OVANDO-MARTINEZ, M.; SAYAGO-AVERDI, S.; AGAMA-ACEVEDO, E. et al. Unripe banana flour as an ingredient to increase the undigestible carbohydrates of pasta. Food Chem., v. 113, n. 1, p. 121-126, 2009. 
PEREIRA, M.C.A. Efeitos das farinhas de polpa e de casca de banana e do fermentado de quefir nos níveis glicêmicos e lipidêmicos de ratos. TESE (DOUTORADO EM CIÊNCIAS DOS ALIMENTOS) - UNIVERSIDADE FEDERAL DE LAVRAS, MG, 2007.

PEUMANS, W.J.; PROOST, P.; SWEENNEN, R.L.; VAN DAMME, E.J.M. The abundant class III chitinase homolog in young developing banana fruits behaves as a transient vegetative storage protein and most probably serves as an important supply of amino acids for the synthesis of ripening-associated proteins. Plant Physiology, v.130, n. 2, p. 1063-1072, 2002.

PIELTAIN, M.C.; CASTAGNON, J.I.R.;VENTURA, M.R.; FLORES, M.P. nutritive value of banana (Musa acuminata $\mathrm{L}$ ) fruits for ruminants. Animal Feed Sc. Tech., v. 73, n.1-2, p.187-191, 1998.

POMERANZ Y. Research and development regarding enzyme-resistant starch (RS) in the USA: a review. Eur. J. Clin. Nutr., v. 46, n. 2, p. S63-S68 1992.

POWELL, KF. HOLT, SHA. MILLER, JCB. International table of glycemic index and glycemic load values: 2002. Am. J. Clin. Nutr., v. 76, p.5-56, 2002.

PUUPPONEN-PIMIÄ, R.; AURA, A.M.; OKSMAN-CALDENTEY, K.M.; MYLLÄRINEN, P.; SAARELA, M.; MATTILA-SANHOLM, T.; POUTANEN, K. Development of functional ingredients for gut health. Trends Food Sci. Technol., Amsterdam, v.13, p.3-11, 2002.

RAFTER, J.J. et al. Effect of calcium and pH on the mucosal damage produced by deoxycholy acid in the rat colon. Gut, v. 27, p.1320-1329,1986.

RAMOS, D. P.; LEONEL, M.; LEONEL, S. Amido resistente em Farinhas de Banana Verde. Alim. Nutr., v. 20, n. 3, p. 479-483, jul./set. 2009.

ROBERFROID MB. Concepts in functional foods: the case the inulin and oligofructose. J. Nutr. v. 129, p.1398-401, 1999.

ROBERFROID, M.B. Functional food concept and its application to prebiotics. Dig. Liver Dis., Rome, v. 34, n..2, p. S105-S110, 2002.

SÁ, N.G. Nutrição e Dietética. Ed. Nobel. $7^{\mathfrak{a}}$ ed. São Paulo, 174p.1990.

SAMBUCETTI, M.E.; ZULETA, A. Resistant starch in dietary fiber values measured by the AOAC method in different cereals. Cereal Chem, v. 73, n. 6, p. 759-761, 1996. 
SÁNCHEZ JLR, PÉREZ MF. Elaboración de productos alimenticios con fibra. La experiencia en Cuba. In: LAJOLO F.M., SAURA-CALIXTO F., WITTIG DE PENNA E, MENEZES EW, EDITORES. Fibra dietética en Iberoamerica: Tecnología y Salud. São Paulo: Varela; . p. 263-6, 2001.

SANDERS, M.E.; KLAENHAMMER, T.R. Invited review: the scientific basis of Lactobacillus acidophilus NCFM functionality as a probiotic. J. Dairy Sci., Savoy, v.84, p.319-331, 2001.

SAQUET, E. et al. Effect of amylomaize starch on cholesterol and bile acid metabolisms in germfree (axenic) and conventional (holoxenic) rats. Reprod. Nutr. Dev., n. 23, p. 783-792, 1983.

SATIN, M. La irradiación de los alimentos. Zaragoza: Acribia. 175 p. 1997.

SAURA-CALIXTO, F.; GARCÍA-ALONSO, A.; GOÑI, I.; BRAVO, L. In vitro determination of the indigestible fraction in foods: an alternative to dietary fiber analysis. J. Agric. Food Chem., v. 48, n. 8, p. 3342-3347, 2000

SHI Y, JEFFCOAT R. Structural features of resistant starch. In: McCleary V, Prosky L. Advanced dietary fibre technology. Oxford: Blackwell Science; p.430-39. 2001.

SIEVERT D, CZUCHAJOWSKA Z, POMERANZ Y. Enzyme-resistant starch III. Xray diffraction of autoclaved amylomaize VII starch and enzyme-resistant starch residues. Cereal Chem., v. 68, p. 86-91, 1991.

SISTEMA BRASILEIRO DE RESPOSTAS TÉCNICAS - SBRT. Rio de Janeiro: Ministério da Ciência e Tecnologia, 2005. Disponível em: $<$ http://sbrt.ibict.br/upload/sbrt 424.pdf>. Acesso em: 22 de Agosto de 2006.

SOUSA, J.P; TORRES, A. P; GOMES, J.J.L; LOPES, L A, P; LOPES , L.A; SILVA, L.A; NASCIMENTO, S.M; COSTA, W.K. A; CONCEIÇÃO, M.L; SOUZA, E.L; BARROS, J.C; OLIVEIRA, M. E.G; Complementação e segurança alimentar: Uma proposta de extensão para comunidades de baixa renda. Centro de Ciências da Saúde/Departamento de Nutrição/PROBEX UFPB-PRAC XI Encontro de Extensão1999.

STREETER, V.L. Mecãnica dos fluidos. São Paulo: McGraw-Hill do Brasil Ltda, 1974.

SUNTHARALINGAM, S. \& G. RAVINDRAN, G. Physical and Biochemical properties of green banana flour. Plant. Foods Human Nutr., v. 43, p.19-27, 1993. 
TAMIKAZU, K.; FURUTA, M.; TODORIKI, S. ET AL. STATUS OF FOOD IRRADIATION IN THE WORLD. Radiat. Phys. Chem., v. 78, p. 222-226, 2009.

TEIXEIRA, M.A.V.; CIACCO, C.F.; TAVARES, D.Q.; BONEZZI, A.N. Ocorrência e Caracterização do Amido Resistente em Amidos de Milho e de Banana. Cienc. Tecnol. Aliment., (Campinas), v.18, n. 2, Maio/Julio, 1998.

TESTER, R. F. et al. Starch - composition, fine structure and architecture. $\boldsymbol{J}$ Cereal Sci, v. 39, p.151-165, 2004.

THARANATHAN, R. N. Food-derived carbohydrates - Structural complexity and functional diversity. Crit. Rev. Biotechnol., v.22, p.65-84, 2002.

THIS, H. Um cientista na cozinha. São Paulo, SP. Editora Ätica S.A., 1996.

TORRES, L.L.G; EL-DASH, A.A; CARVALHO, C.W.P; ASCHERI, J.L.R; GERMANI, R; MIGUEZ; Efeito da unidade e da temperatura no processamento de farinha de banana verde (Musa acuminata, GRUPO AAA) por extrusão termoplástica. Bol. do Centro de Pesquisa de Proces. de Alim., v. 23, n. 2, 2005.

TRIBRESS, T.B.; HERNANDEZ-URIBE, J.P.; MENENDEZ-MONTALVO, M.G.C.; MENEZES, E.W.; BELLO-PEREZ, L.A.; TADINI, C.C. Thermal properties and resistant starch content of green banana flour (Musa cavendishii) produced at different drying conditions. LWT - Food Sc. Technol., v. 42, p. 1022-1025, 2009.

TSEN, C. C. Regular and protein fortified cookies from composite flours. Cer. Food World, v. 21, n. 12, p. 634-637, 1976.

UNIVERSIDADE DE SÃO PAULO (USP) Tabela Brasileira de Composição de Alimentos. Departamento de Alimentos e Nutrição Experimental, FCF-USP. [acesso em 2001 abr 22]. Disponível em: http: //www.fcf.usp.br/tabela. 1998.

URBAIN, W.M. Food Irradiation. Orlando, Florida: Academic Press, Inc 1986.

VAN NIEUWENHUYZEN, W., BUDNIK, V., MEIER, T., POPPER, L. Functional use of hydrocolloids in food systems. Agro. Food Industry Hi Tech., v. 17, n. 5, p. 39-43, 2006. 
VON SONNTAG, $C$. Trends of research in radiation chemistry. In: IAEA. Advanced radiation chemistry research: current status. IAEA-TECDOC-834. International Atomic Energy Agency, Vienna, p. 11-41, 1995.

WALTER, M; SILVA, L.P.S; EMANUELLI,T. Amido resistente: características físico-químicas, propriedades fisiológicas e metodologias de quantificação. Cienc. Rural, Santa Maria, v. 35, n. 4, 2005.

WEBSTER. Webster's Third New International Dictionary, ENCYCLOPAEDIA BRITANNICA, Chicago, G. \& C. Merriam Co, p1732, Inc. 1976.

WEENWN, H.; VAN GEMERT, L.J.; VAN DOORN, J.M.; DUKSTERHUIS, G.B.; DE WUK, R. A. Texture and mouthfeel of semisolid foods: commercial mayonnaises, dressings, custard desserts and warm sauces. J. Sensory Studies, v. 34, p. $159-179,2003$.

WHO. Safety and nutritional adequacy of irradiated food. Genebra, 1994.

YOSHII, F. Radiation processing of polysaccharide derivatives. In: JAERI Conference 2004-007. Proceedings of the FNCA 2003 Workshop on Application of Electron Accelerator, 2003, Kuala Lampur, Malaysia, p. 125-126.

YUE, P.; WARING, S. Resistant starch in food applications. Cer. Food World, v. 43, n. 9, p. 690-695, 1998. 